\title{
1 \\ Karl Llewellyn and the Origins of Contract Theory
}

\author{
ALAN SCHWARTZ ${ }^{\dagger}$
}

\section{Introduction}

Karl Llewellyn was America's leading legal realist, academic law reformer, and contract law theorist. There are extensive analyses of Llewellyn's performance as a realist and reformer, but his contracts scholarship, written between 1925 and 1940, has not been seriously analyzed.' As an example, William Twining's famous study answered the question of what of Llewellyn should be read today as follows: "A number of essays on specific topics are still of value, and this is particularly the case with most of the articles on contract and commercial law of the middle period." But Twining did not analyze any of these articles in detail in a 533-page book. ${ }^{2}$ Similarly, a recent major collection of readings on legal realism has a single chapter on contracts that is twenty-one pages long and has only a two-page excerpt from one Llewellyn contracts article $-(3)$ - that does not set out his views on any contract issue. ${ }^{3}$ Modern scholars commonly infer Llewellyn's views on contract theory from early drafts of the Uniform Commercial Code, from the Code itself, or from Llewellyn's later jurisprudential writings. ${ }^{4}$

The attention that modern scholars pay to Llewellyn and a citation analysis of his work confirm that Llewellyn's contract theory has current relevance. ${ }^{5}$ This chapter evaluates the theory through an analysis of the contracts articles themselves. Turning to the sources sometimes is unnecessary for a figure who is as well known as Llewellyn, but is necessary here because the usual references are not illuminating. UCC drafts, especially those after 1941, reflected the work of several authors as well as what it was politically acceptable to say. ${ }^{6}$ There also are marked differences between the Llewellyn to whom modern scholars commonly refer and the Llewellyn who created the theory (or perhaps differences between the earlier and later Llewellyns). ${ }^{7}$

That Llewellyn's contracts scholarship is largely unread is unsurprising: The articles are opaque to nonspecialists and difficult even for experts. The readability problem should be stressed at the outset because it renders tentative 
any conclusions about what Llewellyn actually believed. The problem does not stem from Llewellyn's inability to write an English sentence or his colorful prose. Llewellyn could write lucidly, but the papers are difficult because Llewellyn pursued multiple objectives when writing them, and overestimated the typical reader's knowledge. A discussion of warranty, for example, will also be a discussion about why warranty doctrine was often confused and how sales law should be regulated generally. Llewellyn commonly expressed views on such issues interstitially, in the context of historical discussions of the law and of business practice (as Llewellyn conceived it) that ranged over a century and covered England and the United States. The papers also assume an audience who had read everything Llewellyn had read, and who had it as clearly in mind when reading as Llewellyn had when writing. Thus the warranty articles cite over a hundred cases but give the facts of a handful; readers apparently are expected to know the facts and holdings of the other cases. A criticism of the rules respecting a buyer's rights when receiving a defective tender assumes that readers know the nineteenth and twentieth century law on conditions, waiver, and damages. Nonspecialists quickly get lost and specialists have problems. These difficulties and others detailed below imply that no interpretation can be definitive, and this one attempts to be cautious.

Before turning to Llewellyn's theory, a few remarks should be made about this chapter's nature and scope. The chapter treats Llewellyn's contracts articles as if they were chapters in the same book. This ahistorical approach to Llewellyn's thought is taken for two reasons. First, ten of the thirteen works were written between 1936 and 1940, and so were contemporaneous in fact. Second, while his analysis grew richer in the period analyzed here, Llewellyn's basic views did not change.

Turning to issues of scope, to understand a theoretical contribution fully requires at least these inquiries: (1) What was the state of theory when the contribution was made? (2) What led up to that state and what changed later? (3) What was the context of discovery for the scholar himself (what did he personally know, read, and so forth)? (4) What was the social setting in the profession (how were new ideas received)? (5) What cultural and ideological factors outside the field of study were influential? (6) What epistemological and thematic notions (i.e., what would a good theory be like?) did the scholar hold? There has been little scholarship concerning questions (1), (3), (4), and (6) in connection with Llewellyn's contract theory, and not a great deal on (2) and (5). No chapter-length treatment can fill this gap. This chapter's contribution rather is to set out the theory itself in a preliminary way, to evaluate this tentative rendering, and to make a few speculations concerning the second and sixth inquiries.

Part II below sets out Llewellyn's theory as a whole and without citation to the work. Documentation, illustration, and critique follow. This part attempts to do what Llewellyn did not - to set the theory out in one place. As said above, 
Llewellyn scattered his theoretical ideas interstitially throughout his writings. Turning directly to the articles thus would be confusing. Part III begins with an illustration of Llewellyn's approach to resolving sales issues, then shows how he thought custom could illuminate adjudication and rule making, and finally elaborates the institutional aspect of the theory - what legal rules could do, who should make them, and what form they should take. Part IV illustrates how Llewellyn found what he believed were the real legal rules (as contrasted with the rules that were taught in law schools), and then analyzes typical Llewellyn law reform proposals. The object here is to see how Llewellyn attempted to solve concrete problems. Part V next examines the freedom of contract aspect of Llewellyn's theory, which has the greatest contemporary relevance. Part VI is a conclusion.

An essay about Llewellyn's contract theory could have two sets of addressees: scholars working today on contract or sales issues who may look to the theory for illumination; and scholars interested in Llewellyn's other work or in legal realism, who may want to know what light Llewellyn's contract theory throws on these broader matters. This essay is addressed primarily to the former group. It argues that Llewellyn's general approach to the legal regulation of contracts remains valuable but his solutions to specific legal problems often are unhelpful. This partly is because many of the economic techniques needed to analyze these problems had not been developed when Llewellyn wrote. Llewellyn's limited knowledge of actual commercial behavior and his failure to pursue his ideas systematically also flawed the work. Regarding this chapter's broader implications, many of the notes below form a subtext that argues that there are important inconsistencies between what Llewellyn and other realists are said to believe and the ideas expressed in Llewellyn's contract articles. This subtext is briefly developed in the conclusion.

\section{The Theory}

Llewellyn's contract theory was meant to tell decisionmakers how to regulate sales transactions. The decisionmakers in the theory were courts and law reform organizations such as the National Conference of Commissioners on Uniform State Laws; legislatures played a minor role. The theory had a substantive aspect (what the legal rules should be) and an institutional aspect (which legal institutions should make the rules and what form the rules should take). Both aspects of the theory implied views that would be regarded as conventional in today's law and economics world.

A theory directed to decisionmakers should identify and motivate its norms. Law reformers then were concerned with efficiency and redistribution. Llewellyn believed that distributional goals had no place in a contract theory because the commercial actors in the theory commonly occupied the two relevant roles of buyer and seller. This multiplicity of roles would vitiate the 
pursuit of distributional ends, for what a party would gain when wearing her seller hat she would lose when wearing her buyer hat. The regnant norm in Llewellyn's contract theory thus was efficiency, as then understood. Llewellyn never explicitly justified the pursuit of efficiency. Rather, he believed that American society had accepted the efficiency norm and he did as well.

\section{A. The Substantive Aspect}

The substantive aspect of Llewellyn's contract theory followed from four premises:

1. Courts should interpret contracts in light of the parties' commercial objectives and the context in which they dealt.

2. Decisionmakers should complete incomplete contracts with rules that reflect the deal typical parties would make in the circumstances.

3. A court should not enforce a contract without an independent inquiry into its substantive fairness if one party's consent to the contract was unconscionably procured.

4. Decisionmakers should reduce the transaction costs of doing deals.

Versions of these premises (except perhaps the fourth) were held by others when Llewellyn wrote. Llewellyn took the first two premises more seriously than his contemporaries did, however. He believed that the typical court or law reformer viewed the commercial world through the distorting lens of taught legal doctrine. This produced the incorrect interpretations and flawed rules that much of his work sought to correct. Llewellyn also was more concerned than other scholars of his time with the question of when the state should restrict private contract. The most original aspect of Llewellyn's work, however, lay not in his recognition of the relevance of these four premises, but rather in the many provocative substantive and institutional implications he drew from them.

Law and economics scholars today commonly attempt to develop contract rules by identifying the cost-minimizing solution to a contracting problem. Thus, an analyst will develop a model to show what contract term respecting damages would be efficient for a particular transaction type. The scholar then will recommend that the law adopt this term as the default solution when the parties' contract is silent concerning damages. Llewellyn seldom worked in this way because the economics of his time were too primitive. Continuing with the example, optimal contract terms respecting damages today are derived as the equilibria of asymmetric information contracting games. ${ }^{8}$ Game theory had not been developed when Llewellyn wrote, so he could not identify game theoretic solutions to the particular contracting problems his theory had to solve. 
Llewellyn thus worked "indirectly": He used commercial practice as the best evidence of the efficient transaction. Parties, he believed, pursued their self-interest when contracting (maximized their expected utility). Hence, the parties' consent to a deal was good evidence that the deal was efficient. It was this method of analysis that made Llewellyn sensitive to freedom of contract issues. When one party dictated the contract terms, an analyst could infer only that those terms maximized the utility of the powerful party, not that the deal was globally efficient. Dictation would occur, in Llewellyn's view, if one party had structural market power or was more knowledgeable or sophisticated than the other. Such "fiat contracts" lacked the epistemological relevance of "bargained for" contracts. Consequently, courts must make an independent inquiry into a contract's normative suitability when a party's consent to the contract was not conscionably procured. To use practice as evidence of efficiency, that is, requires a theory of unconscionability. ${ }^{9}$

Llewellyn also interestingly pursued several implications of his epistemological view that common practice commonly is efficient. The typical judge, he thought, seldom could discern the parties' commercial goals, but a judge could become sophisticated by repeated acquaintance with the facts. Thus Llewellyn was ambivalent regarding the ability of courts to develop good commercial law rules. Judges of unusual ability with an interest in commerce could do well, as could judges on courts that saw many commercial cases. But the ordinary judge needed help. Such judges could find help from three sources: arbitrators, custom, and trade association rules. Arbitrators were helpful, in Llewellyn's view, because they had the expertise to identify the deal the parties actually made.

Llewellyn had a nuanced view of custom and trade associations. He believed that trade custom could be good evidence of the efficient arrangement, but also that the existence of a custom often was irrelevant to adjudication. Custom commonly is challenged in law suits: The party against whom the custom is asserted claims that the custom does not exist or does not apply to the case at bar. Llewellyn was sympathetic to these challenges. Customs, he thought, reflected the solutions to normal business problems, but the disputes that came to court often were caused by exogenous economic shocks. A custom meant to govern in normal times could shed no light on the efficient resolution of unusual - "trouble" - cases. Rather, the court or law reformer must develop the best solution directly.

Llewellyn was similarly cautious regarding the epistemological relevance of trade association rules. If all parties whom a rule affects are represented in the trade association, the rule is a contract between parties of equal bargaining power, and as such is good evidence of the efficient arrangement. Trade associations, however, often imposed rules on outsiders such as unorganized consumers, and these rules were like contracts between parties of unequal 
bargaining power; one could not conclude that such a rule was efficient just because the sophisticated side of the market liked it.

To summarize the substantive aspect of Llewellyn's thought, Llewellyn believed that decisionmakers should enforce, facilitate, and enact efficient commercial arrangements. The decisionmaker could infer the efficient solution from what parties commonly did. Llewellyn's frequent references to the parties' goals, their deals, custom, and rules of the trade thus were epistemological in intention. What is out there is evidence, but not always reliable evidence, of what maximizes social welfare. Contrary to Llewellyn's reputation among some modern scholars, he did not believe that decisionmakers could infer values from facts, nor did he think that the state should delegate lawmaking power to private groups.

When practice did not supply reliable evidence of efficiency, Llewellyn sometimes would derive the transaction cost-minimizing solution directly. For example, he argued that sellers should be permitted to sue for the price when buyers rejected in distant markets. After rejection, either the buyer or the seller could mitigate damages by reselling the goods. A successful price action would force the buyer to resell because the buyer would become the owner. It is efficient to make distant rejecting buyers resell because these buyers have a comparative advantage at maximizing resale revenue: The goods are in the buyer's market, and the buyer commonly knows that market well.

\section{B. The Institutional Aspect}

Contract law rules performed three functions in Llewellyn's theory: to fill gaps in incomplete contracts; to develop and apply appropriate constraints on the parties' freedom to contract; and to direct or "channel" the adjudicator's factfinding function. Creating rules to perform these functions requires expertise, and the rules themselves must be clear. The need for expertise underlay Llewellyn's view that commercial law rules are best created by administrative agencies or specialized law reform organizations. Llewellyn's stress on rule clarity presupposed the ability of rules to guide parties and constrain courts, and Llewellyn accepted this presupposition. Rule scepticism played no role in his theory. Legal rules, he thought, also should ask courts to find facts - which party had possession of the goods when the fire struck? - rather than require conceptual analysis - which party had title when the fire struck? Llewellyn, however, rejected conceptual analysis only at the level of rule application. Otherwise, he admired this form of analysis and sometimes did it.

Llewellyn's thought about rules written for commercial codes was a major exception to these views. Llewellyn believed that codes were difficult to amend, and so would have to be applied in quite varied commercial circumstances. As a consequence, code rules should not reflect solutions to specific 
contracting problems, but rather should constitute normative premises for reasoning or channel the courts' fact-finding function. Llewellyn's position concerning the appropriate level of abstraction for UCC rules thus did not reflect his thought on rules generally.

\section{Critique}

Llewellyn's general substantive and institutional approaches to sales and contract law rules remain relevant. Modern law and economics scholars believe, with Llewellyn, that the state should pursue efficiency in the contract area because efficiency is the only implementable goal. And efficiency should be pursued, by and large, in the ways that Llewellyn advocated: Courts should enforce the deals that parties make, which requires courts to understand the economics of commercial transactions; and doctrine or statute should attempt to reduce the costs to parties of making deals by choosing as the default solution the efficient contract term. Llewellyn's major achievement was to develop this general approach to the legal analysis of contract.

Many of Llewellyn's specific analyses, however, rest on errors and it is therefore a mistake to rely on his recommendations for what should be done in concrete cases. Without the concepts and tools of modern economic analysis, Llewellyn could not understand how market power is acquired and exercised, and so his unconscionability theories are too primitive. He did have perceptive insights respecting when rules should be mandatory or defaults and which transaction costs the state likely could reduce. But because Llewellyn could not understand these concepts as moderns do, his work often is unhelpful. It must also be said, however, that Llewellyn sometimes did not satisfy the standards of his time. Other realists recognized that more can be learned about the world by studying it directly than can be learned from Llewellyn's method of reading appellate opinions with particular attention to the facts. And consistency in thought has always been a virtue. A perhaps illuminating way to summarize this chapter's critique is to remark that Newton's theory remains true over much of the domain it was created to explain, but a fair amount of Llewellyn's work is not true in this sense because it never was true.

\section{Norms, Rules and Institutions}

\section{A. Norms and the Basic Approach}

Llewellyn believed that distributional goals played no role in a contract theory. He explained that "most of the Sales Field is uncolored as most other law is not by the clash of class and passion," because "the same parties, and the same types of party, can tomorrow be occupying each the other end of similar 
disputes." 10 Rather, sales law had to solve "practical" problems: "law and legal rules are practical tools for practical men, and have as their job to center on practical issues. And most conflicts of doctrine do just that."11 Turning to these practical issues, Llewellyn asked, "What, then, are the problems with which it is the business of the mercantile law of Sales to cope? They turn chiefly about occasional hitches in the process known to economists as distribution (which includes assembling), to business-schools as marketing, ... to lawyers as formation and performance of contract. . . ."12

Decisionmakers need a source of policy to resolve even practical issues. Llewellyn sought to increase efficiency by enforcing the parties' deal: Parties should be permitted to make "any contract they please" because "the animals probably knew their own business better than their keeper did-a theory which has not only charm but virtue, most of the time."13 On a slightly more abstract level, "business has been the biggest single man-made fact in our living." 14 Courts therefore have not "failed to reflect the sound American point of view that it is business which makes the wheels go round" and thus "have felt it good to favor" commerce. ${ }^{15}$ In a similar vein, Llewellyn observed that Americans live "in a bargain economy," and that if courts are to enforce contracts, "Benefit of the bargain is the sane standard for a court to enforce by." This also is the law: "Our policy is fixed in most cases in terms of purporting to award Benefit of the Bargain. I think the choice is wise." 16

Llewellyn's adoption of premise (1), that courts should implement the parties' goals, is nicely illustrated by his view of warranty law. He approved of the Uniform Sales Act warranty and presumption rules because these "seek less to lay down controlling rules than to standardize, on the basis of the most general practice discernable, the probable meaning of the acts or words concerned to most bargainers concerned, and to give effect to that meaning. . . . And this, in my view, is the sound basic approach to regulative law about socially unobjectionable transactions which can be reasonably standardized, and where bargaining power is moderately balanced or fair dealing is the practice." 17 The parties' meaning is reflected in their contract. Thus, warranty law should be put "on a contract basis"18: ". . . in the normal modern case the first measure of the parties' rights is not the seller's conduct but the seller's contract. . . . Every problem of modern sales law splits into two major lines of inquiry: according to whether the seller's action does or does not conform with that contract. . .."19

When a contract was incomplete, the court should ask what quality risk the typical seller would assume (this is premise (2)). In the early part of the nineteenth century, that seller was a wholesaler or factor who purchased goods in sealed packages from a distant merchant. The factor thus "sells wares of whose origin, growth, manufacture, handling, packaging, he can have no personal knowledge and may not have even hearsay. Is such a seller to be held 
to quality responsibility unless he [explicitly] warrants?"20 Because sellers would not warrant without knowledge of product quality and buyers would know this, the typical deal would reflect the rule of caveat emptor.

A counter-rule grew "out of factorage, but out of busier factorage." Under caveat emptor, the buyer must make a "full examination of the wares" before acceptance. A seller who warrants that the sample he or she exhibits fairly represents the bulk will "speed turnover" because the warranty substitutes for buyer inspection. The warranty also would increase seller costs, but (the exogenously caused) growth in nineteenth century American commerce would have permitted such a seller to "cover with increased commissions any seller's responsibilities assumed." Therefore, courts who recognized a trade usage that samples are taken to represent the bulk, and who "imposed" implied warranties ... are creating merchants' law for merchants, where farmers' law has ceased visibly to cover merchants' needs." ${ }^{21}$ Many courts, however, took a long time to understand that they should imply the sample warranty because "either view [of the quality obligation the seller must assume] is a view for the passionate furtherance of trade."

The warranty example illustrates the creativity of Llewellyn's approach to creating sales law rules. Llewellyn did not ask what rule sellers and buyers in general would want, but rather what rule parties would agree to given their particular circumstances. This focus on context implied the conclusion that caveat emptor was once the better rule for allocating the risk of nonconforming goods. When commercial circumstances changed, the parties' rule preferences should change as well. Thus, when the volume of trade increased, the increased costs to sellers of making warranties would be more than offset by the gain from additional business. Sellers in this new circumstance would want to warrant. Hence, the law should change so that sellers are taken to make an implied sample warranty when the contract is silent. As also is typical, the economics of Llewellyn's argument are a little off: The volume of trade is irrelevant to the question of which quality risk allocation is efficient; rather, the question is whether factors or retailers could infer the nature of the bulk from the sample more cheaply. For if the costs to factors of learning what the bulk is like are higher than the costs to their buyers of learning this, then a factor could not recover the higher inspection cost attributable to the warranty by selling more goods. ${ }^{22}$

\section{B. The Relevance of Custom}

It is a commonplace that custom played an important role in Llewellyn's theory, but a disagreement exists as to what that role was. The claim here is that custom had epistemological relevance. The first two premises in Llewellyn's theory held that courts should interpret contracts to achieve the parties' goals, and that decisionmakers should complete contracts with rules that typical 
parties would accept. Custom is relevant to decisionmakers, then, to the extent that it evidences what commercial parties want. ${ }^{23}$ In contrast, modern scholars hold that realists, in particular Llewellyn, urged courts to find in commercial practice the norms with which to resolve business disputes. ${ }^{24}$ The articles analyzed here contradict this view.

There are two reasons for custom not to be an independent source of norms for decisionmakers. First, custom often is unhelpful. The law resolves troubled cases, and in troubled cases custom can run out. ${ }^{25}$ Llewellyn explained:

"Business understanding" of what an agreement means, and indeed of whether an agreement exists, is by no means unambiguous and not always adjustable. It is not alone wilful default, but honest difference of opinion, which leads to disputes, and which leaves some proper room for law officials. Both ways and norms of business practice may be firm at the center, but they are hazy at the edge; they offer little sureness to guide in dealing with the outside or unusual case. ${ }^{26}$

The accompanying footnote added:

Practice is, however, rarely marked definitely enough to set a clear standard for judging unusual cases. . . A given trade may recognize unlimited cancellation as of right, in the ordinary course. But in the ordinary course cancellations of given orders do not pile up. Is the freedom to cancel to be regarded as holding equally in a cataclysmic market? One main business of law is to set, to create, norms for such cases of conflicting or uncertain expectation. ${ }^{27}$

Second, to let custom control is to make the cognitive mistake of suppressing a moral premise. If the law is to enforce right conduct, then it cannot direct a result just because it is the result many parties would reach. Rather, while practice is relevant to decision, it is a separate question whether the usual result is the normatively correct result. To decide cases only according to custom thus is implicitly to assume that what is customary is also right.

Llewellyn did not make this assumption, but rather explicitly denied the normativity of the actual. It was false to assert that the realist has "no interest on his part for better law." The error of critics is to assume "that anyone conceives that all law has to do is to follow society because in a particular instance under discussion the following of society is urged to be the adjustment needed." 28 Llewellyn gives as an example that "banking practice" should determine how much time a holder needs to present a check, but there remain "certain regular abuses in the affiliate practices of the same banks" that the state should curb. ${ }^{29}$ In a later analysis, he argued that buyers received too much protection under the nineteenth century factors acts, and added, ". . I hope the doubts I have raised as to the wisdom of this full range of his protection under the . . . [statutes] may guard me from any misinterpretation that I am urging the protection of interests simply because they are, or of the market as it is because 
it is." 30 When doing contract theory, Llewellyn did not attempt to deduce ought from $i$, but rather sought to learn from and improve the $i s .{ }^{31}$

\section{The Nature, Function and Creation of Legal Rules}

Llewellyn's substantive theory as applied to contract rules followed from premises (2) and (4) above - that the rules should be defaults that either reflect the terms that typical parties would adopt or reduce transactions costs. Rules that achieve these functions have to constrain decisionmakers, who are required to apply the appropriate legal default, and guide parties, who need to know what legal result will obtain unless they change the default. Rules that can constrain courts and guide parties must be stated on a low level of generality. A rule that requires parties to behave "reasonably" thus is unsatisfactory relative to a rule that imposes a particular risk on the seller if certain facts are found to exist. Rules that impose commercial risks, in turn, are best created by persons well informed about commerce. Llewellyn's substantive theory thus had these institutional implications: Rules should be concrete; concrete rules can constrain decisionmakers and guide parties; and the rules preferably should be created by experts.

1. RULE FORM. Llewellyn believed that commercial law rules should be concrete: "Nor can they [prevent disputes] if, when found, they are vague: 'do right'; 'do not perpetrate a combination in restraint of trade. . . . The specific character of administrative rules on those technical points which ethics and even custom hardly touch, or touch with no uniformity, is an engineering device of rare value." 32 Llewellyn later softened this view, conceding that a rule may be useful though "rather indeterminate in form"; such rules should be "issue-pointing rules which marshall the relevant factors around the vital criterion." 33 Llewellyn's views on such concepts as "title" and "property in the goods," however, illustrate his preference for the concrete.

This preference followed from his view of what questions a good legal rule should require the decisionmaker to answer, not from a distaste for broad analytical categories or conceptual analysis. ${ }^{34}$ Llewellyn disliked rules that required courts to address questions to the facts that the facts could not directly answer. Thus, the facts could tell who did what and when but could not tell where "title" to the goods was because title is a legal concept. To be sure, a rule holding that title was in party $\mathrm{S}$ if facts $\mathrm{x}$ and $\mathrm{y}$ were found, but otherwise was in party $\mathrm{B}$, could be applied intelligently. Where title was, however, determined legal consequences, such as who bore the risk that the goods would be destroyed before the contract was performed. As a consequence, a legal rule could simply state that party $S$ bore the risk of such a loss if facts $x$ and $y$ were found but otherwise party B bore the risk. Title is "a wholly unnecessary major premise." 35 Making the application of a rule turn on legal concepts such as title 
is unwise as well as unnecessary. A rule meant to tell courts what questions to address to the facts is more likely to be applied correctly if the rule requires an explicit factual inquiry - did fact $\mathrm{x}$ exist? - rather than a conceptual inquiry where was title? As Llewellyn said in another context, meaningful rules are defined by "operative fact" rather than "legal consequence." 36 A meaningful rule thus is specific, not abstract. ${ }^{37}$

Llewellyn's preference for precision in rule statement was not an objection to the width of analytical categories in legal analysis or to the use of conceptual analysis in general. Llewellyn disliked bad concepts, not concepts per se. ${ }^{38}$ Indeed, Llewellyn sometimes urged a widening of the then-regnant categories of legal analysis. Thus, he argued that warranties and remedies should be considered together because whether or not a warranty is found has meaning only in so far as legal consequences flow. ${ }^{39}$ Llewellyn also considered warranties in connection with other doctrines. For example, some nineteenth century courts in his view correctly expanded the scope of the seller's quality obligation but then vitiated the expansion in face-to-face sales by taking the buyer to waive defects when he or she accepted the goods: "no damage remedy survived your accord and satisfaction." 40 The courts' mistake was to treat the connected issues of substantive liability and waiver as if they were separate. ${ }^{41} \mathrm{In}$ accident law, the appropriate category for analysis was not food but rather the uninformed consumer purchase of potentially dangerous products. ${ }^{42}$ Finally, the field of contract law itself is too narrow an analytic category: The appropriate category is "transactions," which should include corporate law and property. ${ }^{43}$

In Llewellyn's theory, wide analytical categories, conceptual analysis, and concrete rules thus easily coexist. The former two modes of thought help the scholar or decisionmaker to choose the appropriate rule, which in turn will constrain courts and guide parties if cast in concrete form. Llewellyn departed from these views only when considering rules that were to appear in a code. In Llewellyn's view, codes differed from ordinary statutes along the dimension of amendability: "a codificatory Act" is not "ordinary legislation" because "it is not legislation capable of easy or frequent amendment; errors in it . . . are rather to be suffered ... over very considerable periods." 44 Uniform laws meant to codify fields had not been amended frequently when Llewellyn wrote, but he provides only a mystical explanation: "The Code of a Field builds itself into the life and work of men; it cannot be lightly altered." 45 In any event, such a code cannot "long answer the needs of a whole field. It therefore makes judicial development (not mere 'interpretation') a necessity." 46 A good code should facilitate judicial development by stating principles and directing courts to reason by analogy from them: Courts should be made to realize that "the act is a freshly stated take-off from explicit, true common-law principle into the common-law type of development of true common-law principle." 47 There is little or no evidence in these articles, however, indicating a Llewellyn belief that a code is the best lawmaking vehicle. 
2. THE ABILITY OF RULES TO GUIDE AND CONSTRAIN. Llewellyn held that doctrine is "a convenient and fairly accurate summation of past decisions and of apparent trends, one which makes possible the intelligent decision of a new case in the light of its bearing on doctrine and on life." 48 Llewellyn thus told students "that the examination gives no room at all for policy discussion except after the positive rules prevailing have been brought into play upon the problem; that policy discussion after the question is decided and the relevant authorities considered will be welcome; otherwise disregarded." 49 That rules can decide cases implied for Llewellyn that, "Rules must be framed to hold up - and hold down - judges who are not supermen."50 And also, "judges are by no means free to be 'arbitrary', and must be held down and directed." 51 This is a common theme. 52

Llewellyn at least once sought to demonstrate that rules could reduce disputes. He analyzed two negotiable instruments principles, one dealing with bona fide purchasers of commercial paper and the other requiring notice to conditional obligors. The former principle "is expressed in the Negotiable Instruments Law in rather broad language setting up standards"; the latter "is expressed in a multitude of detailed rules." The former approach, Llewellyn observed, generated far more litigation than the latter. Hence, "I conclude that, along with principle, rules have their realm of service."53

Other evidence suggests that the Llewellyn of these articles did not believe that law was best made by drafting statutes stating broad principles and then letting courts apply the principles. Llewellyn remarked that judges "sit as laymen groping to solve a controversy [in this case, chattel security law, but the point was general] they cannot understand." 54 A softer version of this view pervades Llewellyn's early work, in which a constant theme held that the law was often confused or wrong because courts did not understand commercial situations. This failing could not be cured by giving courts vaguely worded statutes to enforce. Llewellyn gave this example: Sellers financed sales early in the nineteenth century, but by the 1870 s, bank financing had become prominent. The courts never perceived this switch, and so failed to read the Factors Acts to facilitate bank financing. 55 The early Acts, he concluded, were later "mutilated in American seaboard courts . . . when the main fact picture which the judge sees, knows . . . has come to change."56 Only statutes that tell courts what questions to address to the facts can prevent such disasters.

Though Llewellyn believed that rules could constrain courts, it is too simple to say that he defined law merely as a set of predictions of what the courts will do. ${ }^{57}$ To be sure, he believed that, "If it is moderately clear how future cases will come out, then a statement of that clarity is the Rule of Case-Law . . . irrespective of whether it is a nice rule or a wise one or a just one." 58 Statutes also are controlling rules in this sense, whether the statutes are nice, wise, or just. Llewellyn went further, though, to distinguish between rules for lawyers and rules for courts. One could "challenge the title of rules for counselors to be 
called rules of law at all; for such rules are not normative; they command nothing. . . . They are of the nature of a weather forecast. . ."59 In contrast, the judge is to choose the "wise" or "just" rule. ${ }^{60}$ Rules for counselors can be called rules, however, because the function of a rule is to guide conduct, and counselors' rules do that. Nevertheless, the distinction between rules for lawyers and rules for judges should always be kept clear.

3. RULE CREATION. Implementing the results of Llewellyn's contract theory requires expertise. A court could develop expertise if it were presented with a line of cases that repeatedly raised the same issues: "fact-pressures, if they can be canalized and kept moderately repetitive, give us some fair quantum of wise case-results." But whether courts get repetitive cases is a matter of chance, ${ }^{61}$ and having the cases is only a necessary condition for getting efficient rules: Also needed are "a prophet and a suitable doctrine." 62 Prophets, however, are unusual: Holmes and Mansfield "stand out because of rarity." 63 The rules therefore should come at least in part from outside the common law system.

Llewellyn thus repeatedly expressed a preference for specialized decisionmakers. These were desirable both because of their expertise and because they could develop specific rules. Llewellyn's preference for expert decisionmakers was expressed early: "legislatures ... though better adopted for general policy-shaping than courts, are by both size and membership hampered in doing the legal engineering. . . . Legislators, too, are only men, and in technical fields, laymen." An administrative tribunal is best: "It offers means of developing experts specialized in their fields, of getting quick decisions, and, above all, of getting a wealth of detailed specific rulings." 64 Similarly, public or quasi-public bodies could best effect law reform: It would be good to have "the creation of some agency which serves in private law as the cop serves in public law: an appointed person who will do what it has been discovered George will not." Examples include the National Conference of Commissioners on Uniform State Laws and the New York Law Revision Commission. ${ }^{65}$

Courts played a residual but significant role in the theory. Society faces a scarcity of regulatory resources, but parties always can sue. In a discussion of standard form contracts, Llewellyn said "administrative supervision . . . is to be welcomed" but "new fields" emerge and agencies are hard to create. Consequently, we need "a judicial technique built to face the problem in its always new forms." 66 And when public regulation of product quality waned, "then private remedy on private agreement became the law's one immediate hope."67

Private parties also can fill the regulatory gap. After noting that juries may not reliably understand commercial custom, he remarked, "This is one point at which commercial arbitrators have a tremendous advantage over lawyers," and he added that "for the mercantile man," the remedy for bad law lay in good drafting and arbitration. ${ }^{68}$ Trade associations also could substitute for bad or 
absent law. A trade association could best develop "the working rules of a technical activity" 69 because, "In the self-government of sub-groups contract provides an original framework, a constitution, a source of ultimate sanction in dispute or breakdown." 70 More precisely, trade associations reduce disputes by specifying the quality obligation that sellers must meet and by providing the parties with better decisionmakers than courts. Llewellyn, however, would uphold trade association rules only when all affected parties participated effectively in the trade association. The rules emerging from such a process would be balanced, and thus as deserving of enforcement as ordinary contracts. ${ }^{71}$

\section{Illustrative Substantive Views}

Llewellyn described himself as a "Contract theorist", and defined the role: "the theorists . . . have as their first objective to state accurately and neatly what the courts have been doing" and "to do criticism only after stating accurately and neatly what it is that they are criticizing."72 Part IV first focuses on how Llewellyn stated the law and then illustrates his mode of criticism. The object is to give a richer statement of Llewellyn's theory by analyzing two of his major concerns.

\section{A. Stating the Law}

The taught doctrine and the words of statutes, Llewellyn thought, differed substantially from the law that courts applied. This theme pervades the articles, but appears most clearly in the offer and acceptance papers. The first began with the claim that the taught doctrine differed from the living law, and stated the thesis that one can work up from the cases "a rather coherent and workable body and moderately simple body of case-principle and even often clean caselaw about the formation of business agreements. . . ."73

Llewellyn used the method of normal science to state the law - induction from good data. An analyst using the inductive method states a preliminary hypothesis, gathers the data, sometimes refines the hypothesis, and then tests it. Llewellyn self-consciously worked in this way. He said, "The emphasis on rules and, in our own case law, the particular emphasis on the derivation of rules from case-to-case decision focuses particular attention on the problem of induction." 74 He then cautioned:

without a hypothesis which unambiguously means one thing, attempted observation or research into new data or old is somewhere between 90 and 95 per cent waste motion. Granted ... that the hypothesis conditions observation. ... Granted . . that the shaping and fixing (partly by the hypothesis) of the multicolored data in turn conditions the conclusion. . . The fact remains. Without the unambiguous hypothesis, no advance. ${ }^{75}$

In the offer and acceptance articles (and generally), Llewellyn's preliminary hypothesis held that "case-law doctrine in Contract . . . is likely both to reflect 
life-conditions and to stay moderately close to them." 76 The taught doctrine then distinguished between bilateral and unilateral contracts. Under the former, the offeror wanted a return promise as the acceptance so the offeree could accept by promising. Under the latter, the taught doctrine took the offeror to want a return performance as both an expression of acceptance and as the consideration for the offeror's promise. Hence, the offeree could not accept an offer to make a unilateral contract merely by saying that she would perform it. This taught doctrine, Llewellyn thought, was inconsistent with practice: "in life, expressed agreement does operate as a commitment. It just does." 77 Typical parties thus would assume that both were bound when the offeree said she would perform; the distinction between unilateral and bilateral contracts "represents doctrine divorced from life." 78 This led to the refined hypothesis: "This [assumption by parties that there was a deal] is business; it is sense; it will be surprising if it does not prove to be at least majority case-law."79 Llewellyn's admittedly nonexhaustive survey then showed that American caselaw did not distinguish between bilateral and unilateral contracts; rather, a seriously meant expression of assent commonly was held to bind the offeror.

Llewellyn's use of the inductive method was not unique. Arthur Corbin also sought to infer the actual law from case data. The novelty in Llewellyn's method was to assume that courts did (as well as should) further business goals, and thus to derive his hypotheses respecting what the law was by asking what rules would advance these goals. The weakness in Llewellyn's use of the method also derived from its novelty: The method cannot be used correctly if the analyst does not know what business practice is and why. As is well known, Llewellyn took much of his knowledge of practice from appellate court opinions. In a typical treatment, he once remarked that certain warranty contracts had attracted so much attention from nineteenth century courts that one "is forced to believe" that the contracts were "becoming familiar in practice." 80 It is preferable to look directly at the practice. Llewellyn also sampled cases rather than collected them exhaustively. ${ }^{81}$ Llewellyn's views about what the living law then was thus should be regarded as hypotheses, not facts.

\section{B. Criticism and Reform}

Llewellyn as a law reformer sought to implement the second and fourth premises of his theory. These held that the state should create efficient default rules (2) and enact transaction cost reducing rules (4). Llewellyn thus said of the realist enterprise, "There is a strong tendency [of realists] to approach most legal problems as problems in allocation of risks, and so far as possible, as problems of their reduction. . . . To approach . . . business matters, in a word, as matters of general policy." 82 Llewellyn explicitly applied this approach to commercial law. The introduction to his sales law casebook stated, "the book . . . views the contract as a device for allocating various business risks; it takes 
up the presumptions [i.e., defaults] of Sales Law as a device for allocating risks which parties have not expressly covered." 83 The law could allocate risks with default rules (he called them "yielding rules") or with mandatory rules ("rules of iron"). ${ }^{84}$ A fault of the Uniform Sales Act was to be unclear about which of its sections were mandatory and which were not. ${ }^{85}$ This section of the chapter examines three Llewellyn proposals to reform the law of sales. These proposals illustrate a thesis of this essay: The premises of Llewellyn's theory were sound but he often implemented those premises imperfectly because he lacked the right economic tools.

1. SELler's ACTION FOR THE PRICE. Llewellyn sometimes pursued transaction cost reduction explicitly when recommending specific reforms: The applicable "general policy reasoning" is to have "speed and cheapness of adjustment." 86 In particular, the question of when the seller should get the price should be answered on the basis of "a careful canvass of the business and economic bearings of the competing choices." ${ }^{7}$ Llewellyn used this canvass to conclude that the seller should be limited to damages if breach occurred when the seller had the goods: "To force such goods on the buyer, when they are reasonably marketable by the seller, is social waste. ..." Making the vendor resell when the buyer breaches after delivery, however, has two disadvantages: The duty to resell would be "burdensome" for the seller and thus imposing this burden on the seller would give the buyer excessive power in a renegotiation; and the seller does not know the local market as well as the buyer does. "This presents a case that tips the balance of social utility in favor of forcing title on the buyer." 88 This analysis remains apt in many markets today. ${ }^{89}$

2. COVER. The law when Llewellyn wrote permitted a disappointed promisee to recover market damages - the difference between the contract and market prices measured at the time of breach. Llewellyn argued that the promisee in the alternative should be permitted to seek cover damages - the difference between the contract price and the price of a substitute transaction. The availability of cover damages would permit parties to avoid expensive actions to prove a market price. Cover also would facilitate renegotiation, which reduces the costs of resolving disputes..$^{90}$ When only market damages were available, Llewellyn argued, a breached-against buyer would make a substitute purchase at once; for if the buyer waited and the market rose, market damages would not make the buyer whole: The buyer would have bought at a high price but will have his damages measured by the lower price prevailing at breach time. The market damage rule thus discouraged a buyer from attempting to salvage the deal privately. The buyer, however, would negotiate with his seller for a reasonable time after breach if he could have his damages measured by the cost of a substitute purchase should the negotiations break down. "Given such a provision [for cover], a buyer can negotiate with his defaulting seller with no more fear of the market than afflicts any business man. . . ."91 
As with many of Llewellyn's specific substantive claims, the economics of the argument are not exactly correct. The modern view holds that market prices incorporate all publicly available information. As a consequence, market participants perceive new price-affecting information as generated by a random process. This implies that the next period's price for goods is today's price plus interest plus an error term with positive variance and mean zero. Put less technically, a commercial actor with rational expectations and no inside information will assign an equal probability to market increases and decreases. Applying this theory to the problem at hand, a buyer who could get only market damages would face conflicting incentives. Contrary to Llewellyn's argument, the buyer has a reason not to make a substitute transaction immediately. If the market fell after breach, a buyer who waited to repurchase would profit from default: He would have bought at a low price but have his damages measured by the high price that existed on the date of breach. And as Llewellyn recognized, the possibility of a price rise after breach creates an incentive for the buyer to repurchase at once. Since the buyer would believe that a fall is as likely as a rise, the buyer would assume that the price will not change. ${ }^{92}$ Such a buyer would negotiate with the breaching seller if that seemed helpful and otherwise purchase on the market. Giving a buyer only market damages thus will not discourage renegotiation.

In addition, adding cover damages to the remedies a disappointed buyer can assert would produce overcompensation. To see why, recall that when cover becomes available, the buyer is permitted to measure damages at the more favorable of two dates: breach or cover time. The buyer thus is given a free option to speculate after breach. Because options are valuable, adding a free option to the buyer's damage remedies overcompensates him. ${ }^{93}$ Llewellyn's advocacy of a cover remedy thus was flawed in three ways: First, making cover available will not increase the likelihood of renegotiation; second, it was contradictory of Llewellyn to argue that the law should protect the expectation interest and also permit a buyer to cover (because cover overcompensates); and third, Llewellyn never analyzed the decisionmaker's real choice, which is whether to facilitate deals by reducing the promisee's costs of proving damages or to impede deals by adding a supra compensatory remedy. ${ }^{94}$ The primitive state of financial economics in Llewellyn's time likely would have caused any analyst to make these errors. ${ }^{95}$

3. SUbStantial PERformance. Llewellyn's views on the perfect tender rule illustrate well the strengths and weaknesses of his substantive analyses. A strength is attention to context. He perceptively argued that perfect tender ("recision for minor defects") is appropriate for consumers and for buyers of machines for use. In the former case, the rule "fits the case of the wallpaper which is just enough off-color, or the radio which is just enough off true, to edge the nerves." In the latter case, perfect tender is appropriate because "a 
machine even slightly defective can disrupt processes." Perfect tender is not appropriate for manufacturing buyers of such inputs as "print-paper, chemicals, leather, or wool" unless these are to be used in "the choicest manufactured product." Perfect tender never is appropriate for mercantile buyers.

Llewellyn objected to a perfect tender rule in mercantile transactions because the rule would encourage what today is called strategic behavior: "It [the rule] is an invitation to throw back the risk of any dropping market upon a seller who has performed as a reasonable seller should perform." 96 Buyers would "throw back the risk" by rejecting on the basis of defects that would not have produced rejection had the market gone their way. Such rejections are breaches of the real contract that the parties thought they had made (which imposed the risk of price increases on the seller and of declines on the buyer). To enforce the real contract thus is to preclude rejection, but the real contract also did not require the buyer to pay the full price for defective goods. When the goods were "gradable . . . or moderately gradable," the custom, Llewellyn believed, was to have price allowances. A decisionmaker would enforce the true deal - premise (1) of Llewellyn's theory - by following this custom. ${ }^{97}$

Llewellyn's reform proposal was to generalize the custom by having the legal default permit courts to bar rejection but order price allowances in mercantile transactions. In 1940, he urged an amendment to the proposed Federal Sales Act that would have banned rejection in sales between merchants if "the delivery offered in no material manner increases the risk resting on the buyer, and is of such character as to reasonably meet the buyer's operating requirements, so that an appropriate reduction of the price can serve as adequate compensation for failure of exact performance." 98 An analysis of this suggestion shows that Llewellyn did not appreciate the parties' contracting concerns as well as a modern scholar would, and also did not study business practice seriously. Llewellyn's proposed rule conditions on information that courts will not have. The rule requires a court (i) to cost out "the risk resting on the buyer" in order to decide whether the defective tender increased that risk in a "material manner"; (ii) to know the buyer's production function in order to decide whether the defective tender nevertheless "reasonably meets the buyer's operating requirements"; and (iii) to trace the financial consequences to the buyer of a "failure of exact performance." Information respecting these issues commonly is unverifiable. That is, it seldom would be cost-justified for parties to ascertain the actual risks the promisee faced, her production costs, and her expected profits, and so to verify to a court data respecting these.

Default rules that condition on unverifiable information are objectionable because they produce moral hazard. ${ }^{99}$ Here, a seller may attempt to force the buyer to take a defective tender because, the seller may plausibly think, the buyer could not rebut the seller's claim that the tender "reasonably met the buyer's operating requirements." In addition, there seldom is a market price for 
every quality level of a product, from the perfect to the almost worthless. Thus, establishing an "appropriate reduction of the price" for a defective tender also may cost parties more in litigation expenses than they are willing to pay. The evidence unsurprisingly suggests that merchants respond to the strategic rejection concern with rules more precise than this proposed law. 100

Llewellyn's advocacy of substantial performance probably was consistent with his advocacy of expert decisionmakers because there is some evidence that he wanted the issue decided by a merchant jury. ${ }^{101}$ The availability of an expert trier of fact, however, would not respond fully to the difficulty raised here, for that difficulty goes less to a decisionmaker's lack of expertise than to the decisionmaker's inability to access the relevant information (because the parties will not provide it). Once again, an analyst writing when Llewellyn did could easily miss this point because the economics of his time missed it.

In sum, Llewellyn encouraged the state to adopt efficient defaults and to reduce transaction costs. ${ }^{102}$ This approach is now conventional. Llewellyn, however, seldom could apply this approach productively because he lacked modern tools of economic analysis. The approach requires the analyst to understand commerce at the level of the individual transaction. This understanding is hard to acquire without a knowledge of game theory, transaction cost economics, and finance. None of these economic specialities were well developed when Llewellyn worked. ${ }^{103}$

\section{Freedom of Contract}

Llewellyn paid considerable attention to freedom of contract issues - see premise (3) - because of the epistemological role that actual contracting played in his theory. When parties contracted under ideal conditions, the deal would maximize the utility of both. However, "free contract presupposes free bargain, and . . free bargain presupposes free bargaining." 104 Hence, "where bargaining power, and legal skill and experience as well, are concentrated on one side of the type-transaction," the transaction is not necessarily efficient but rather "is a form of contract which, in the measure of the importance of the particular deal in the other party's life, amounts to the exercise of unofficial government of some by others via private law." 105 In such cases, judicial review or regulation is necessary to ensure fairness: "When drafting [by the powerful] began to gain ground, it thus became not only an enterpriser's measure, but a social menace. ... The menace calls for 'public' measures of control and cure."106

Llewellyn believed that there was less free bargaining in his time than previously because of the increasing use of standard form contracts and the growth of powerful trade associations and companies. As he said, "once ... [the] process of agreeing" involved the freedom to choose and "choice with some inkling of consequence." But at the time when he was writing, there were 
standard form contracts and "differential knowledge, power and bargaining skill. . . . This means need for control, lest old rules based on Adam Smithian postulates be made tools of outrage." 107

These views were the premise to Llewellyn's unconscionability thesis: Contracts that are substantively objectionable ("lop-sided") should not be enforced when the bargaining process that produced them was procedurally defective. An unconscionable term commonly withdrew something that the weaker party valued. A disclaimer, for example, eliminated warranty protection. Thus to hold disclaimers unconscionable is to make the warranty term mandatory, and this is what Llewellyn believed should be done: "so far as . . . rules of implied warranty are intended to control contractors, they must be rules of Iron nature, and must therefore not be subjected to contracting out."108 When the structural factors that support a finding of unconscionability would continue to exist, Llewellyn believed, the state thus should require the results that it desires. Default rules are appropriate when bargaining power is roughly equal. Otherwise, to permit contracting out of the law would result in "penalizing little men while bigger outfits bargain out."109

These perceptive views helped to organize the unconscionability debate that began in the 1960s and continues. ${ }^{110}$ The views, however, were general. A workable theory of unconscionability should provide criteria specifying when a contract is too lop-sided to enforce and when a contracting process is importantly defective. Llewellyn was unable to develop these criteria. In their place, he developed questionable concepts whose implication was that procedural defects were ubiquitous. These concepts led him to be more interventionist than his general theory otherwise would support. Part V thus continues a theme of Part IV: Llewellyn helped to develop what is today the basic approach to regulating contracts for fairness but could not apply this approach productively, in considerable part because he lacked the requisite economic tools. ${ }^{11}$

\section{A. Substantive Unconscionability and Remedies}

On Llewellyn's view, a contract is substantively unfair if it is "lop-sided," not "balanced." 112 A lop-sided contract imposes too many risks on one party. The law is balanced - "Bodies of yielding rules [i.e., defaults] have grown some balance in their allocation of risks and rights" 113 - but strong parties create imbalance when they contract out.

Llewellyn could not say how much imbalance was too much. He remarked: "the policy of leaving . . . yielding rules free to change by individuated bargain does not involve commitment to a policy of allowing displacement of the whole set of yielding rules at once, and without individuation"; "there must be decent balance in the frame of contracting which is to hold for all points not individuated by the parties." 114 These views only restate the question. ${ }^{115}$ Llewellyn did claim that a contract which shifted the quality risk entirely to the 
buyer was lop-sided,"116 and advocated "legislative intervention, prohibiting certain clauses and prescribing others. . ." 117 Apart from outlawing warranty disclaimers, however, he never clearly said what legislatures were to do.

Llewellyn's unembellished directive to decisionmakers to achieve "balance" in contracting thus seems inconsistent with his belief that a good commercial law rule will address to the courts factual questions that courts are capable of answering. Llewellyn attempted unsuccessfully to resolve this tension in his thought by developing methods of analysis to guide judicial inquiry. Initially, he rejected the standard judicial technique of construing the language in unfair contracts against the drafter. Ignoring the drafter's intent would create too much uncertainty. "No man is safe when language is to be read in the teeth of its intent." 118 Also, when a court strikes a term, firms using it respond by drafting a substantively identical but linguistically different term. As a consequence, the process of construing contracts against drafters is often wasted effort. 119

Llewellyn recommended two other judicial techniques. First, a court should read the contract to contain what the weaker party would expect the contract to contain. His earliest major article thus advocated giving "the insured ... the protection he might decently believe he was buying, without too close regard to the exceptions of the policy." 120 Fourteen years later, he argued that, "when bargaining is absent in fact," courts should "read into" a form contract the terms "which a sane man might reasonably expect to find on that paper."121 One of the drafts of the Article 2 revision adopts this technique. ${ }^{122}$

The "reasonable expectations" standard on which the technique rests can be either factual - courts should ask what terms a buyer actually should expect to have purchased - or normative - courts should ask what terms a buyer would expect the seller to offer if the seller were behaving fairly. Llewellyn apparently wanted courts to employ the technique in both of its senses. Thus he said that courts should strike terms that are inconsistent with trade practice. ${ }^{123}$ This view implies a factual standard: Buyers actually would expect their seller to use the industry term unless the seller said otherwise, so courts should read contracts to contain industry terms. A substantive unconscionability inquiry would be relatively predictable if the standard for the legally permissible were the widely acceptable.

Llewellyn, however, did not want to limit the inquiry in this way. As said previously, he rejected the idea that the law should follow a custom just because the custom existed. Relevant here, Llewellyn believed that buyers should be taken to expect terms that corresponded to the holdings in the cases $^{124}$ because the common law contained a set of balanced default rules. Also, the common law refines notions of fairness in the course of deciding new cases. A buyer thus could reasonably expect his seller to offer terms that corresponded to current conceptions of fairness. Therefore, Llewellyn is plausibly read as arguing that courts should use both the factual and the normative 
aspects of the reasonable expectations test when deciding whether a contract term is substantively conscionable.

The difficulty here is that the normative aspect yields unclear rules. To see why, realize that Llewellyn's use of a normative test is circular: He holds that courts should give buyers what buyers expect, which is balanced clauses, and that buyers expect what courts give them, which is balanced clauses. This circularity exemplifies a general problem: A normative reasonable expectations standard necessarily collapses into some other substantive test. Under the standard, courts should give the buyer what he is morally entitled to expect, and he or she is morally entitled to expect substantively conscionable terms. Thus, the normative reasonable expectations test merely restates the inquiry, for the test reduces to a directive to courts to strike substantively unfair terms and add substantively fair terms. ${ }^{125}$ Since Llewellyn devised the reasonable expectations test because he was unable to distinguish what was fair from what was not, his thought here is unhelpful.

Llewellyn's second proposed technique for guiding a substantive unconscionability inquiry directed courts to focus on transaction types. "The proper judicial aim seems to me to be here the fixing ... of a basic minimum which the bargain carries merely by virtue of being a bargain of that type. But that would imply a limitation on contractual capacity. . . ."126 Llewellyn also referred approvingly to the English idea that "the quality obligation ... is something inherent in the deal: a basic minimum from which Contract may spring-board but which Contract will not be allowed to undermine." 127 And again, courts should not enforce a standard term that is "repugnant to the balanced nature of the type of transaction which the parties have obviously entered on." 128

Llewellyn appears to claim that sales transactions come in types that private parties cannot alter. This claim could rest on the view that sales are natural kinds whose essence is that sellers bear certain risks, such as the risk that the goods will not perform in the described manner. Words in a contract could not alter a particular transaction type's essence any more than calling a lion a sheep will make the lion docile. If Llewellyn held this view, he would have made a category mistake. The question for the state is not what a "sale" is, but what terms in sales contracts should be legally enforceable. This is a normative question. Thus directing a court's attention to a transaction's "type" also is unhelpful. 129

To summarize, Llewellyn's theory held that when true consent to a contract was lacking, the state should instead enforce the contract that would be fair. Llewellyn, however, could not develop criteria specifying when a contract was fair - that is, substantively conscionable. This failure led him into inconsistency. According to Llewellyn, courts should resolve questions of contractual fairness by reference to a party's "reasonable" expectations, to a transaction's "type" or to whether a contract was appropriately "balanced." These tests do 
not identify the facts that should tell a court whether to find for the seller or the buyer. Llewellyn, however, justified his rejection of the title concept by arguing against rules that did not call for clear factual inquiries. Recall Llewellyn's claim that a court should allocate the risk of loss of the goods by asking which party had possession of them when the loss occurred, not by asking which party had title to them then. A consistent Llewellyn would also claim that a court should decide whether to enforce a disclaimer by asking (for example) which party had a comparative advantage at reducing the defect risk, not by asking whether a disclaimer was consistent with a buyer's "reasonable" expectation or a particular "transaction type." It is a puzzle why Llewellyn rejected unhelpful concepts for some legal areas but not others.

\section{B. Procedural Unconscionability}

1. THE STANDARD APPROACH. Llewellyn was an important originator of what has become the standard approach to procedural unconscionability. He believed that bona fide consent to a contract term was absent when one side had market power, or when one side was more sophisticated or knowledgeable than the other. ${ }^{130}$ Llewellyn also believed that competition among sellers sometimes would protect buyers, ${ }^{131}$ but competition by "the contract-dodger" more commonly will degrade "standards of performance generally." Apparently in consequence of this latter phenomenon, the commercial "tendency" has been to have "seller-protective instead of consumer-protective clauses." 132

These views also were held on a high level of generality. The related imperfect information and market power concerns are illustrative. A buyer would be uninformed if he (i) was unaware of what the contract said or of the legal consequences of the words used; (ii) could not evaluate the risks he understood the contract to impose on him; or (iii) understood the deal offered to him but did not know what offers competing sellers would make or were making. Llewellyn never distinguished among these senses of the imperfect information concept. These distinctions are important to make because the law should, and now often does, respond to these forms of imperfect information in different ways. Plain language laws respond to form (i), requiring firms to quote contract terms in a standard fashion responds to form (iii) (by reducing search costs), while no policy response to form (ii) is today generally considered to be efficacious.

Llewellyn also believed that market failure existed when all firms in a market used the same terms. This assumes that the relevant unit of analysis, in consumer markets, is the individual transaction. As Llewellyn recognized in other contexts, however, mass transactions occur in these markets and it would be inefficient to alter standard form contracts to suit the preferences of individual buyers. Therefore, buyers do best when the market itself is competitive, for then every firm prices at cost and buyers receive the entire surplus that sales 
create. That all firms charge very similar prices or use very similar terms is consistent with either a monopoly or a competitive equilibrium. ${ }^{133}$ In the former case, consumers engage in little search about market alternatives because information acquisition costs are high. Firms commonly respond by charging supra competitive prices. In the latter case, consumers engage in considerable search, in consequence of which all firms are compelled to price at the cost of the low cost producer. ${ }^{134}$ Thus nothing normative follows from the similarity of prices or contracts alone. Rather, the decisionmaker must evaluate the competitive state of the market in which the contract was made.

Llewellyn therefore deserves considerable credit for helping to invent the conceptual vocabulary in which unconscionability discussions have been held since he wrote, and to have introduced the useful distinction between procedural and substantive unconscionability. Llewellyn, however, deployed this apparatus in a primitive way. Again, this largely is due to the primitive state of the economic analysis of his time. ${ }^{135}$

2. AN EXTENSION OF THE STANDARD APPROACH. Llewellyn advocated banning warranty disclaimers without direct evidence of defects in the bargaining process. He argued that in the nineteenth century, "mercantile-mindedness of any court leads towards widening seller's obligation, whether implicit or constructive," and, "also to giving a decent buyer some remedy in the case in hand." 136 The doctrine that governed how different warranties related to each other had become confused. Llewellyn thus proposed an amendment to the Uniform Sales Act stating that courts should construe warranties as consistent with each other, but if this could not be done the "order of preference" should be that blueprints should control samples that should control merchantability warranties that "arise without words." Llewellyn added a substantive proviso to this interpretative section:

Provided, however, that any express clause negating or modifying warranties, conditions or remedies provided by this [Sales] Act for the buyer is presumptively void; and provided further that any party setting up such a clause shall carry the burden of alleging and proving, first that the party against whom the clause is invoked has freely agreed thereto; and second, that the clause lies within the reasonable region of self-regulation by parties. 137

Thus, a disclaimer could be unenforceable although the buyer has "freely agreed thereto," if the disclaimer falls outside the "reasonable region of selfregulation by parties." In line with this view, Llewellyn later suggested adding to the warranty section of a proposed Federal Sales Act the words, "The warranty herein is not subject to negation." 138

Llewellyn recognized that disclaimers were widely used. Given his view 
that widespread contractual practices likely are efficient, a disclaimer thus for him should lie within the "reasonable region of self-regulation by parties." Excluding disclaimers from this region thus seems inconsistent with Llewellyn's more general views. Llewellyn did not perceive an inconsistency, however, because he thought that the usual warranty clause was the product of procedural defects.

Llewellyn came to this questionable view because he took an ex post approach to the subject. To see what is meant, suppose the buyer purchased goods that turned out to be worthless and the seller had disclaimed warranties. Llewellyn reasoned backward from the buyer's unfortunate position to the contracting stage. A well-informed buyer would not consent to a deal that left him with worthless goods. Hence, he said of cases that sought to help the weaker party, "The lop-sidedness of bargain-result is thus taken as the mark of lop-sidedness of bargain making,"139 and later that, "A bargain ... shows itself not to be a bargain, when lop-sidedness begins to scream." 140 Procedural defects were even more likely when the price was substantial. Llewellyn thus approved of an alleged older practice under which, "In merchants' sales of wares a sound price warrants a sound article, merchantable and proper to pass as a sound ware under the designation. ..."141 It followed that a seller behaved wrongfully if she assumed no obligation respecting quality but charged a sound price. ${ }^{142}$ The link between this conclusion and the existence of procedural defects is found in Llewellyn's approval of "Holmes' observation that the price paid for a contract commonly negates expectation of unusual risk."143 In sum, the coexistence of broad exculpatory language with a high price almost conclusively evidences defects in the contracting process.

The mistake here was to neglect the parties' contracting problem. A warranty is an insurance policy that protects a buyer against losses attributable to the goods. A full warranty - complete insurance - would create moral hazard: The marginal cost to the buyer of reducing the probability of a loss would be positive while the marginal gain from buyer investments in prevention would be zero because the full warranty would already have protected the buyer against any loss. Hence, the buyer would be careless. A common remedy for moral hazard is coinsurance: The insurer - the seller-bears some risks, and the insured - the buyer - bears others. The more risk the insured bears, the more careful he will be. Therefore, both full warranties and complete disclaimers are rare. Under the usual practice, the seller warrants against harms that she was likely to have caused or which she could repair most cheaply, but does not warrant against harms that commonly result from buyer misuse or against which the buyer could best insure. ${ }^{144}$ Because informed buyers would agree to bear some product risks, it is incorrect to infer bargaining failure from the presence of uncovered risks alone. Rather, the analyst must either identify bargaining failure directly or show that an efficient warranty contract would have imposed on the seller the risk that the buyer was made to bear. 
Llewellyn's argument that high prices imply the existence of warranties is similarly flawed. The argument can be illustrated in this way: Let a buyer purchase a stereo system for $\$ 1,000$. If the system were defective, it would be worth nothing. When the seller charges $\$ 1,000$, then, she is affirming that the stereo is worth that much. Buyers expect to have remedies when seller affirmations turn out to be untrue. Hence, the buyer who pays the $\$ 1,000$ price expects that the seller agrees to bear the quality risk - that the seller has made a warranty. The error in this reasoning is to analyze the problem after sale. Then the stereo is worth either $\$ 1,000$ or zero. Buyer inferences respecting the contract's risk allocation must be drawn at the time of sale, however, and the stereo then is worthless only with a particular probability. If that probability is low, then the product is worth a lot without a warranty, and will sell for an appropriately high price. Hence, the contract price alone cannot support a plausible buyer inference that the seller has made a warranty. This point perhaps is clarified with an example.

Assume that a firm sells a stereo that is produced at a constant marginal cost of $c$. The probability of a defect is $\pi$, and a defect makes the stereo worthless. The firm makes a warranty that requires it to replace worthless units. The firm thus must produce more units than it makes sales in order to be able to replace nonconforming units, and the replacement units also could be defective. Solving this problem, a firm that warrants would have to produce $1 /(1-\pi)$ units to "support" each sale. If the firm sells $x$ stereos in a period, its total variable cost is $c x /(1-\pi)$, and the marginal cost is $c /(1-\pi)$. When the firm prices at the minimum of its average cost curve (i.e. the market is competitive), the fixed cost that each sale recovers is $\mathrm{f}$. The stereo's price with a warranty thus is $p_{w}=f$ $+c /(1-\pi)$. The stereo's price without a warranty would be $p_{n w}=f+c$. Suppose that $\mathrm{f}=\$ 100, \mathrm{c}=\$ 1,000$, and $\pi=.01$. The transaction price when the firm warrants would be $\$ 1,110.10$, and the price when it disclaims would be approximately $1 \%$ lower, $\$ 1,100$. This example shows that rational buyers would pay almost as much for products with disclaimers as for products with warranties. It thus is incorrect to claim that whenever the price is nontrivial, buyers expect their sellers to have made warranties. ${ }^{145}$

To summarize, Llewellyn's advocacy of a disclaimer ban in merchant markets is formally consistent with his views on freedom of contract generally because he believed that buyers did not consent to disclaimers freely. Llewellyn, however, inferred this lack of consent from the property of disclaimers to impose risks on buyers and the penchant of sellers to charge prices that, given product failure, seemed high. This inference was mistaken. When it is rejected, the inconsistency in Llewellyn's thought is restored. Llewellyn's error here is understandable given the limited economic knowledge of his time. He helped to develop what is now called the exploitation theory of warranty, under which sellers disclaim warranties to exploit buyers. A modern treatment of the subject concluded, "The exploitation theory ... 
does not provide any explanation of the existence of warranties. Therefore, it is unclear why warranties can serve exploitative ends."146 Explanations for the existence of warranties, in turn, emerge out of the recent literatures on moral hazard and adverse selection.

Again, Llewellyn had an intelligent approach to freedom of contract issues. He recognized the epistemological relevance of the buyer's consent and the need to develop substantive criteria of contract enforcement when free consent is lacking. On a methodological level, he correctly held that procedural and substantive unconscionability were jointly necessary and sufficient conditions for nonenforcement. He also recognized that many equilibria in consumer markets were (and remain) normatively suspect because information is costly to acquire, structural market power sometimes exists, and consumers tend to be less sophisticated than firms. However, he could not progress with the concrete questions of when and how the state should intervene in consumer markets given the economic tools available to him. And even on his own terms, his freedom-of-contract views sometimes were inconsistent with his more general views on how commercial law rules should be written and on the relevance of widespread practice to efficiency assessment.

\section{Conclusion}

Karl Llewellyn's contract theory can be analyzed on two levels of abstraction. On the high level, Llewellyn's general approach to the legal regulation of contracting behavior is powerful and current. Llewellyn understood that the law had three tasks: to enforce the parties' deal when the deal was discernable, to create default rules to complete incomplete contracts, and to mark the limits of freedom of contract. Llewellyn justified the law's performance of the first task on efficiency grounds and used the efficiency norm to help the law perform the second task. Llewellyn's commitment to efficiency also informed his analysis of freedom of contract, for he thought that efficiency was unlikely when the bargaining process was conducted under much less than ideal conditions, and the results of such flawed processes therefore were not entitled to the law's deference. On the lower level of application of the approach, Llewellyn seldom is relevant to us. Llewellyn could only work with the tools he had, and those tools were too primitive for the task he set himself. It is difficult to make much progress on the creation of good default rules or on developing criteria for efficient interventions in markets without a knowledge of game theory, transaction cost economics, and the economics of information. Because these bodies of knowledge were created after Llewellyn worked, many of his particular applications were mistaken. In addition, Llewellyn was a poor empiricist (at least in economic areas), and he was not always consistent in his thinking. Nevertheless, Llewellyn's general approach easily accommodated itself to the 
use of new economic tools and indeed facilitated their introduction. In this significant sense, he was the major founder.

Before turning to more general themes, it is worth remarking of the danger, when doing interpretation, of finding what one is looking for. Llewellyn also wrote in jurisprudence, sociology, and legal anthropology, and he has been variously identified as a jurisprudent, sociologist, and anthropologist. He is described here as a lawyer economist. This new description should not be taken as an implicit rejection of the others. The different interpretation developed above is partly explained by the use of a different data set - the contracts scholarship - but the difference has a deeper cause. Llewellyn did applied normative analysis in these papers: His central question concerned how the law should best regulate sales transactions between merchants. There are today protests against economic imperialism - can economic analysis explain sex?but it is becoming a consensus that economics has much to say about markets. This essay's description of Llewellyn thus should not surprise, for its claim is only that when Llewellyn wrote in contracts, he took an intellectual approach that was appropriate to the subject.

As for the relevance of the papers discussed here to broader jurisprudential issues, it will be helpful to set out briefly what have become the standard views of realism:

1. Realists believed that the law inevitably is and should be instrumental; legal rules should self-consciously implement policies.

2. Realists had an anticonceptual bias, which led them to reject broad analytical categories, such as "title" and "property," because these obscured what was at stake when choosing rules.

3. Realists, however, were vague respecting what policies the state actually should pursue. They tended to call for policy analysis rather than do it, and many of them were ethical relativists.

4. Realists held a philosophically indefensible view of law, as being only a set of predictions of what courts will do.

5. Realists were rule sceptics, who believed that precise rules could not bind courts, and perhaps could not confine a decisionmaker's discretion very much.

6. In consequence of (4) and (5), realists believed that there was no separation between law and politics.

7. Realism was not a jurisprudence of the modern regulatory state, but rather was court-centered - more so than the situation of American society would warrant.

Llewellyn has been associated with all of these positions, and has been defended against only (5).147 The first view does apply to Llewellyn, who described himself as a legal reformer. There is little support in the contract 
articles for associating Llewellyn with the other positions. These articles show that Llewellyn did not reject conceptual analysis or broad analytical categories, but rather rejected legal concepts that directed to courts questions that courts could not answer; he explicitly believed that the state should promote efficiency by reducing transaction costs and by enforcing business contracts, subject to a fairness constraint that he worked hard (though unsuccessfully) to make precise; he rejected the view that the law was no more than a set of predictions of official behavior; and he believed that rules could seriously constrain a decisionmaker's discretion. Llewellyn did spend much of his time with the law in courts, but out of a sense of necessity. He believed in the superiority of regulatory solutions to many of the problems he discussed, but also thought that there was a scarcity of lawmaking resources so that the ability of parties to sue each other implied that the residual role of courts would remain large in the contract field. Llewellyn did not address the relation between law and politics in these papers because he believed he was addressing problems that did not deeply divide people morally: The American ethos implied the pursuit of efficiency in the contexts he considered, so for him sales law raised technical rather than political issues.

This disjunction between Llewellyn as a contracts scholar and the views that realists generally are perceived to hold raises a methodological point. Realism on the ground may have differed from realism in the air. Perhaps the substantive work of other realists should be read to see whether this distinction holds generally.

\section{Notes}

$\dagger$ This chapter benefited from workshops at Georgetown, Harvard and Yale Law Schools, and a seminar at the Haas School of Business, Berkeley. Helpful comments also were made by Bruce Ackerman, Ian Ayres, Jack Balkin, Richard Craswell, Hanoch Dagan, Dan Kahan, Alvin Klevorick, Brian Leiter, Stephen Morse, Eric Posner, George Triantis, Richard Posner, Steven Walt, and James Whitman.

1. The terms "contract theory" and "contracts scholarship" are meant here to include Llewellyn's work on sales law. The scholarship is found in (1) The Effect of Legal Institutions Upon Economics, 15 Am. Econ. Rev. 665 (1925); (2) Introduction to Cases and Materials on Sales (1929); (3) What Price Contract? An Essay In Perspective, 40 Yale L. J. 704 (1931); (4) On Warranty of Quality and Society I, 36 Colum. L. Rev. 699 (1936); (5) On Warranty of Quality and Society II, 37 Colum. L. Rev. 341 (1937); (6) Through Title to Contract and a Bit Beyond, 15 N.Y.U. L. Rev. 159 (1938); (7) The Rule of Law in Our Case-Law of Contract, 47 Yale L. J. 1243 (1938); (8) On Our Case-Law of Offer and Acceptance I, 48 Yale L. J. 1 (1938); (9) On Our Case-Law of Offer and Acceptance II, 48 Yale L. J. 779 (1939); (10) Across Sales, on Horseback, 52 Harv. L. Rev. 725 (1939); (11) The First Struggle to Unhorse Sales, 52 Harv. L. Rev. 873 (1939); (12) Book Review, 52 Harv. L. Rev. 700 (1939); (13) The Needed Federal Sales Act, 26 Va. L. Rev. 558 (1940). Citations to these works are by integer, as in 3 at 705 . Llewellyn 
wrote several articles advocating the adoption of the Uniform Commercial Code after 1940 , but did no further work in contract theory.

2. William Twining, Karl Llewellyn and the Realist Movement 368 (1973). Twining also does not discuss these papers in The Ideal of Juristic Method: A Tribute to Karl Llewellyn, 48 U. Miami L. Rev. 119 (1993).

3. American Legal Realism, W. W. Fisher, M. Horowitz, and T. W. Reed, eds. (1993). See also, e.g., Laura Kalman, Legal Realism at Yale (1986) (extensive discussions of Llewellyn, but none of his contract work).

4. E.g., Brian Leiter, Rethinking Legal Realism: Toward a Naturalized Jurisprudence, 76 Tex. L. Rev. 267 (1997); Lisa Bernstein, Merchant Law in a Merchant Court: Rethinking the Code's Search for Immanent Business Norms, 144 U. Pa. L. Rev. 1765 (1996); Dennis M. Patterson, Good Faith, Lender Liability, and Discretionary Acceleration: Of Llewellyn, Wittgenstein, and the Uniform Commercial Code, 68 Tex. L. Rev. 169 (1989); Zipporah B. Wiseman, The Limits of Vision: Karl Llewellyn and the Merchant Rules, 100 Harv. L. Rev. 465 (1987); Ingrid M. Hillinger, The Article 2 Merchant Rules: Karl Llewellyn's Attempt to Achieve the Good, the True, the Beautiful in Commercial Law, 73 Geo. L. J. 1141 (1985).

5. The twelve articles that appeared in law reviews were cited 426 times between 1972 and January of 1999. This would be a large number of citations for a modern set of private law articles. The third article, What Price Contract?, was twenty-eighth on the list of the thirty most-cited articles in the Yale Law Journal as of 1991, and was the oldest article on the list. See Fred R. Shapiro, The Most-Cited Articles from The Yale Law Journal, 100 Yale L. J. 1449, 1462-3 (1991). The citation figures for each article are (1) 16; (3) 130; (4) 36 ; (5) 44 ; (6) 27 ; (7) 14; (8) 20: (9) 17; (10) 24; (11) 20; (12) 67; (13) 11.

6. The political constraints under which uniform law drafters work are analyzed in Alan Schwartz and Robert E. Scott, The Political Economy of Private Legislatures, 143 U. Pa. L. Rev. 595 (1995).

7. Anthony Kronman argues that Llewellyn's later thought on issues of method differed substantially from his views in the period analyzed here. Anthony T. Kronman, The Lost Lawyer 196-201 (1993). For similar views, see William C. Heffernan, Two Stages of Karl Llewellyn's Thought, 11 Int'l J. Soc. L. 134 (1983); Wilfrid E. Rumble, Jr., American Legal Realism 147-54 (1968).

8. See, e.g., Aaron Edlin, Cadillac Contracts and Up-Front Payments: Efficient Investment under Expectation Damages, 12 J. Law, Econ. \& Org. 98 (1996); Benjamin E. Hermalin and Michael Katz, Judicial Modification of Contracts Between Sophisticated Parties: $A$ More Complete View of Incomplete Contracts and Their Breach, 9 J. Law, Econ. \& Org. 230 (1993).

9. Llewellyn's theory sometimes collapsed the difference between substantive and procedural unfairness. A "lop sided" contract, he often said, is unfair because knowledgeable parties would not voluntarily agree to it. Such a claim offers the substantive defect as sufficient evidence of the procedural defect. Part V. A below pursues the implications of this type of claim.

10. 10 at $725-6$.

11. 8, n. 55 at 27 .

12. 6 at 164 .

13. 5 at 403. Llewellyn later said: "Almost any particular clause included in a deal represents 
the parties' joint judgment . . . and this alone is good enough for letting it . . displace and replace the general law." 12 at $700-1$.

14. 10 at 725 .

15. Ibid. at 734 .

16. 6 at $175-6$. Llewellyn's view presupposed "mercantile outfits who have bargained on a moderately equal footing." Id.

17. Ibid. n. 72 at 197.

18. 4 at 701. Llewellyn praised Mansfield because he "had laid down the root of the whole mercantile approach to 'warranty': that it rests in contract." 4 at 719. Mansfield's warranty theory is thoughtfully analyzed in James Oldham, Reinterpretations of 18thCentury English Contract Theory: The View from Lord Mansfield's Notes, 76 Geo. L. J. $1949,1969-79$ (1988).

19. 2 at xiv. Again, "Dealers' obligations can be reckoned in terms of . . what the dealer has engaged to deliver, rather than what in semi-tort he should be held accountable for not delivering. . ." 4 at 728 .

20. 11 at 885 .

21. Ibid. at 836. The sample warranty is express today but was implied in the nineteenth century. For readers unfamiliar with Commercial Law, an implied warranty arises without words. For example, when the contract is silent, a merchant seller is taken to guarantee product quality; the seller makes an implied warranty of merchantability. An express warranty is in effect a promise relating to quality - that the goods are machined to a certain tolerance. The seller makes an express warranty by using words: The seller must say that the goods are machined in a certain way.

22. The volume of trade would be relevant to risk allocation if there were economies of scale to making warranties. Whether scale economies regarding the sample warranty existed in the nineteenth century seems unknown, and Llewellyn did not consider the point.

23. Llewellyn saw, " pictures in judges' heads of what trade looked like, and what trade meant, as going far to determine what type of quality obligation they read into the dicker of the parties ... . Common to all [the nineteenth century cases] is a picture of the way in which dickers of this kind typically happen, and so of how the parties ought to have understood what was said and done." 4 at 719, 722. Courts who hold correct pictures of what business parties want to do thus will construe commercial contracts correctly. This is said in 11 at 880-1 and implied often, and is consistent with the modern notion that "commercial norms will develop only if they provide merchants with a more costeffective method of adopting commercial practices on average than the alternative of each merchant starting from scratch." Jody S. Kraus, Legal Design and the Evolution of Commercial Norms, 26 J. Legal Stud. 377-8 (1997).

24. Articles claiming Llewellyn believed that dispute-resolving norms were immanent in practice, and that courts thus should discover and implement these norms, include Richard Danzig, A Comment on the Jurisprudence of the Uniform Commercial Code, 27 Stan. L. Rev. 621 (1975); Kenneth Casebeer, Escape from Liberalism: Fact and Value in Karl Llewellyn, 1977 Duke L. J. 671; Alexander M. Meiklejohn, Castles in the Air: Blanket Assent and the Revision of Article 2, 51 Wash. \& Lee L. Rev. 599 (1994); Allen R. Kamp, Between-the-Wars Social Thought: Karl Llewellyn, Legal Realism, and the Uniform Commercial Code in Context, 59 Albany L. Rev. 325 (1995).

25. Llewellyn held that, "Disputes are the eternal heart and core of law. They do not mark its 
circumference, but they will always mark its center. . . . when two people are in a dispute ... not otherwise settled, . . . law shows its first societal value: the cleaning up of the matter. ..." Legal Tradition and Social Science Method - A Realist's Critique, in Brookings Institution, Essays on Research in the Social Sciences 89, 91 (1931). Llewellyn's general thought respecting law and the troubled case is described in Twining, supra note 2 , at $160-1$.

26. 3 at 722 .

27. Ibid., n. 45 at 723 . Practice nevertheless remains relevant because the decisionmaker must act "in the light of the standing practices to which the new norm will be added, or on which it places a limiting definition." Ibid. Modern scholars argue that appeals to custom as a source of norms can be mistaken because norms can conflict, be vague, or were not meant to apply to the type of case that gets litigated. See Paul Gewirtz's Editor's Introduction to Karl Llewellyn, The Case Law System in America xx (1933, 1989); Jay Feinman, Promissory Estoppel and Judicial Method, 97 Harv. L. Rev. 678 (1984); Chris Williams, The Search for Bases of Decision in Commercial Law: Llewellyn Redux, 97 Harv. L. Rev. 1495 (1984). Llewellyn anticipated these views.

28. 6 at 162 .

29. Ibid. n. 5 at 162 .

30. 10 at 903 . This was the second such disclaimer in these articles. In an earlier discussion of how a counselor would be a little at sea when the decisions were inconsistent, Llewellyn remarked, "This does not mean that I think that without practice there is no law, nor that I think law must follow custom, even when custom is silly or wrong." $7, \mathrm{n}$. 39 at 1257. Llewellyn's thought here is consistent with the view that decisionmakers can materially improve commercial norms with selective interventions. See Kraus, supra $n$. 23.

31. Modern scholars sometimes claim that Llewellyn wanted courts to resolve commercial cases according to the court's "situation sense." It is unclear what this would mean precisely - see Twining, supra $n$. 2 at 217-25, for a statement of the ambiguities - but seems to mean roughly that a court which had a proper understanding of the facts could infer the regnant norm and should follow it. A recent attempt to use the situation sense notion to solve a concrete problem - when there should be a substantial performance rule - is Todd Rakoff, The Implied Terms of Contract: Of 'Default Rules' and 'Situation Sense, ' in Good Faith and Fault in Contract Law 191 (J. Beatson and D. Friedmann, eds., 1995). Llewellyn used neither the phrase "situation sense" nor the concept in the articles analyzed here, and appears not to have done so in anything he wrote before 1941. Rather, the "early Llewellyn" rejected the method of finding norms in practice.

32. 1 at $671-2$. Recall Llewellyn's view that sales law raised mainly technical issues.

33. 8 n. 22 at 10 .

34. William W. Fisher III included Llewellyn in his claim, "the Realists argued that most extent legal concepts had to be disaggregated if they were to be of any use. . . . Concepts like 'title', 'property right' . . . were hopelessly general." William W. Fisher III, The Development of Modern American Legal Theory and the Judicial Interpretation of the Bill of Rights, in M. Lacey and K. Haakonssen, eds., The Bill of Rights (1994). The text next argues that Llewellyn's dislike of the concepts Fisher mentions did not rest on their generality.

35. 2 at xiv. See also 6 at $169-70 ; 10$ at $728-36$. 
36. 8 at 28.

37. Meaningful rules are "understandable and clear about what action it is which is to be guided, and how . . . [and] must state clearly how to deal with the raw facts as they arise." 8 at 12 .

38. As another example of Llewellyn's views, he said of George Gardner's An Inquiry into the Principles of the Law of Contract, 46 Harv. L. Rev. 1 (1932): "He attempted a restatement of Principles in Hierarchy; a beautiful and (for our modern case-law) a novel idea; both method and substance deserve attention which they have not received. The method not only of carefully formulating a principle, but of carefully formulating not a single one ad hoc, but a number of competing principles, in the light of a whole picture; and then not of simply posing them in competition, but trying to arrange machinery for choice among them: this is almost as fine a contribution to juristic method as is Corbin's relentless and unremitting search for and of the cases and his insistence on making any theory square with them." 7 at 1267 . Llewellyn added that he wrote (7) "in sudden worry that some folk might think an attack on pseudo-rules, of case-law . . to be an Attack on Rules, or on Concepts at large." Id. at 1269. In the same vein, see Karl N. Llewellyn, $A$ Realistic Jurisprudence - The Next Step, 30 Colum. L. Rev. 431 (1930).

39. 2 at xiii-xiv.

40. 10 at 887 .

41. 4 at 726 makes the same point.

42. 5 at 404 .

43. 3 at 748 . See also 7 at $1266-7$.

44. 13 at 561 .

45. Ibid. at 564 .

46. 5 at 381 .

47. 13 at 563 .

48. 2 at $\mathrm{ix}-\mathrm{x}$. Llewellyn later added

"A rule which states accurately the outcome of the cases, seen as cases, incorporates pro tanto such wisdom on the cases as prior courts have shown, and such similarity of reaction as courts are likely to continue to show. ... [The rule] gives some guidance (to the judge) about wherein his more personal judgments on such matters may be wisely tempered. It further sets . . . the picture of how far he is or is not really free to move unimpeded, and shows where the penumbra of his honest freedom lies to make further use of the given multiple case-law techniques."

7 at 1257.

49. 2 at $\mathrm{xx}$.

50.8 at 19 .

51. Karl Llewellyn, On Reading and Using the Newer Jurisprudence, 40 Colum. L. Rev. 581,587 (1940)

52. For example, "rules in the proper sense always have as their office to guide action." 8 at 11. In an earlier treatment, Llewellyn said an ideal caselaw rule would fit a consistent line of caselaw, be announced in the cases as the rule, and would "appeal today as leading to a just result." Such ideal rules would guide courts "with some sureness" and afford "a counselor a moderately accurate prediction, and an advocate a solid base of caseplanning." 7 at 1256. Brian Leiter, supra n. 4, argues that the "Realists' Core Claim" is 
that caselaw results are predictable not because rules facilitate predictability but rather because "psycho-social facts about judges" heavily influence decisions, and these factors "are not idiosyncratic but characteristic of significant portions of the judiciary." Ibid. at 284. Llewellyn did not deny the relevance of "psycho-social facts" in the articles reviewed here, but did believe that courts decided according to rules, so that knowing the actual rules (rather than the doctrinal rules) would permit moderately accurate predictions.

53. $8 \mathrm{n} .25$ at 12 . Llewellyn's belief that rules can be clearly put also is evidenced by his view that "certainty is of the essence of mercantile law; business could not proceed without it." 10 at $733-4$.

54. 1 at 670 .

55. 11 at $901-2$.

56. Ibid. at $900-1$.

57. Since H. L. A. Hart, realists, including Llewellyn, commonly are read to define law in this way. See, e.g., David Luban, Lawyers and Justice: An Ethical Study 20-4 (1988); Thomas W. Bechtler, The Background of Legal Realism, in Law in a Social Context 12 (1978); H. L. A. Hart, The Concept of Law, Ch. VII (1961).

58. 7 at 1248 .

59. 8 at 10 .

60. Ibid., n. 21. Llewellyn often distinguished the functions of lawyer and judge. In an earlier paper, he stated that "prediction, not critique of wisdom, is the base-line job of the counselor; whereas the judge has as one of his two base-line jobs to get a wise and just result." 7 at 1256 . And in a later paper, Llewellyn added: "For a counselor at work on counseling, what the courts $d o$ is thus the most important part of law; whether, I repeat, the doing is right or not. But judges (trial judges or appellate) cannot see law that way. . . . the branch of Jurisprudence which deals with the judge and his function must center no less upon the 'just' solution than upon the solution which other courts will reach. . . " Karl N. Llewellyn, On Reading and Using the Newer Jurisprudence, 40 Colum. L. Rev. 581, 593 (1940). Llewellyn also argued that Holmes' statement that the law is only what courts will do was not meant to be taken literally, and was inconsistent with much of Holmes' thought. See 8 at 13.

61. Some European states had set up "specialized tribunals" that were "built for canvassing ... trade practice. . . . But our own history shows that such specialized machinery is not an essential condition to the coming about of such [good legal] results. Given time enough. And given just a little luck." 11 at 874 . The time is needed for cases to come, and the luck is needed to ensure that the cases present repetitive fact patterns.

62. 11 at 876 . See also 877,879 .

$63.8 \mathrm{n} .44$ at 21 .

64. 1 at $671-2$.

65. 5 at 380 .

66. 12 at 705 .

67. 4 at 718 .

68. 5, n. 132 at 392,394 .

69. 1 at 672 .

70. 3 at 730 .

71. That the contribution of trade associations at creating rules lay more in their expertise 
regarding commerce than regarding morals may be inferred from Llewellyn's view that association rules sometimes "have carried lop-sided manipulation into the game of Sales Law - and especially as against the ultimate-consumer buyer"; the state should check this tendency. 5 at 394. Llewellyn earlier argued that trade association rules "may threaten the unorganized consumer. . . . Until counter-organization of consumers develops, the only help for such a case lies along lines of government action." 1 at 677 . Modern scholars extend Llewellyn's view to argue that the norms operative within private groups may themselves be inefficient. See Eric A. Posner, Law, Economics, and Inefficient Norms, 144 U. Pa. L. Rev. 1697 (1996), and Avery Katz, Taking Private Ordering Seriously, 144 U. Pa. L. Rev. 1745 (1996).

72. 7 at $1259,1269$.

73. 8 at 1 . Llewellyn previously remarked, "There is often enough very considerable implicit and silent consistency in actual decision even when announced rules are at odds." 7 at 1252.

74. Karl Llewellyn, Legal Tradition and Social Science Method-A Realist's Critique, reprinted in Karl N. Llewellyn, Jurisprudence: Realism in Theory and Practice 92 (1962).

75. Ibid. at 94 .

76. 9 at 779 .

77. Ibid. at 804 .

78. 8 at 36 .

79. 9 at 796 .

80. 5 at 352 .

81. Useful modern examples of inducting actual contract rules from exhaustive case surveys are Douglas Laycock, The Death of the Irreparable Injury Rule, 103 Harv. L. Rev. 687 (1990), and Edward Yorio and Steve Thel, The Promissory Basis of Section 90, 101 Yale L. J. 111 (1991).

82. Karl Llewellyn, Some Realism About Realism-Responding to Dean Pound, 44 Harv. L. Rev. 1222, 1255 (1931).

83. 2 at $\mathrm{xv}$.

84.8 at $728-30 ; 12$ at 704 .

85.5 at $384-5$.

86 . 6 , n. 63 at 193. Llewellyn's acceptance of the efficiency norm has been remarked previously. Twining, supra n. 2 at 126 (Llewellyn was "a pragmatic, old fashioned American liberal, whose most important operative values were equality of opportunity, individual responsibility and efficiency."); Allan R. Kamp, Uptown Act: A History of the Uniform Commercial Code: 1940-49", 51 S. Methodist L. Rev. 275, 283 (1998) ("There are three themes that constantly recur in Llewellyn's thought: the primacy of trade usages; the goal of modernistic efficiency; and the need for balanced trade rules.").

87. Ibid., n. 29 at 178.

88. Ibid. at 177 . See also 10 at 735 . The gulf between Llewellyn's method and that of earlier scholars is illustrated by comparing Llewellyn's treatment of the seller's price action to the doctrinal article, John Barker Waite, The Seller's Action for the Price, 17 Mich. L. Rev. 282 (1919).

89. Another example of this mode of thought is Llewellyn's defense of the mailbox rule, which holds that the acceptance of an offer becomes effective when the acceptance is 
mailed rather than when it is received. According to Llewellyn, the typical offeree believes the deal is on when he mails his acceptance and so will begin to engage in reliance. The typical offeror, on the other hand, will not think the deal is on until she receives the acceptance, and so she will delay reliance until then. Therefore, holding that the deal is on - the acceptance is effective - when the offeree mails it ensures that "we can protect the offerees in all these deals at the expense of hardship on offerors in very few of them." 9 at 795. This is a standard Kaldor-Hicks justification for a legal rule. The justification may risk circularity, however, without an explanation of how the parties' beliefs are formed. If the offeree believes that his acceptance binds because the law so provides, then the offeree's belief cannot be urged as a justification for the law. Thus Llewellyn's views respecting the mailbox rule are sketched only to illustrate his commitment to reducing transaction costs.

90 . 3 at $737-8 ; 6$ at $180-2,204 ; 13$ at 568 .

91. 6 at 209. Llewellyn recognized that parties could create a cover remedy for themselves but argued that the law should provide the remedy to protect small, unsophisticated firms: "But why should sane rules be limited to the use of the careful and informed who can afford to pay counsel who are also skillful and informed?" Ibid., n. 39 at 182. Llewellyn commonly justified the need for default rules on this ground. See, e.g., 5 at 393.

92. To make this point clear, put interest to one side, denote the current period as period $t$ and the next period as $t+1$, and assume that the market price can rise by ten or fall by ten. Then if today's price is $p_{t}$, a buyer will assume that the next period price is $p_{t+1}=p_{t}$ $+.5(10)+.5(-10)=p_{t}$.

93. This is an "other things equal" result for which limitations on recovering damages may sometimes produce undercompensation, for which a free option would be a partial remedy. In any event, the result may be clarified by an example. Assume that the market and contract prices when the deal was made were 10 and the buyer valued performance at 15 . The buyer's expected profit thus is 5 . The seller breaches when the market price is 12. Suppose that the legally reasonable time for cover would expire three days after breach. Let the buyer in this example have the ability to cover when the seller breached or any time thereafter. The buyer would wait until the third day. If the buyer covered at breach time, he would pay 12, get damages of 2 , and earn his expected profit of 5 (the 2 in damages plus the difference between his valuation -15 - and the cover price-12.). If the buyer waited three days to cover and the day three market price is 12 or more, the buyer would sue for cover damages and also earn his expected profit. For example, if the market price on the third day is 14 , the buyer earns $14-10$ (damages) $+15-14$ (profit on purchase) $=5$. If the market price on day three is less than it was at breach time, the buyer also will cover but sue for market damages, and thus will be overcompensated. For example, let the market price on day three be 11 . The buyer who waits to cover but sues for market damages then will earn $12-10$ (market damages) $+15-11$ (profit on purchase) $=6$. The value to the buyer of the free option that the cover remedy creates - the value of waiting until the third day to cover - is positive because the buyer can profit from a downward market movement but cannot lose from an upward one. In this example, when the market is as likely to rise as to fall, the option is worth $.50(.5(0)$ $+.5(1)=.50)$. Making cover available thus ensures the buyer an expected payoff in the event of breach that exceeds his expectation: this payoff here is 5 (expected profit) +.50 
(value of option) $=5.50$. A court using the good faith standard perhaps could require the buyer to sue for the cover price rather than market damages when the buyer makes one purchase, as in this example. However, plaintiff buyers usually are dealers who make many transactions. A court seldom could restrict such a buyer to measuring damages by any particular post-breach purchase. Dealer buyers thus could speculate in the fashion described.

94. Parties prefer remedies that do not overcompensate. See Lars A. Stole, The Economics of Liquidated Damage Clauses in Contractual Environments with Private Information, 8 J. Law, Econ. \& Org. 582 (1992); Alan Schwartz, The Myth That Promisees Prefer Supra Compensatory Remedies: An Analysis of Contracting for Damage Measures, 100 Yale L. J. 369 (1990).

95. Modern examples of applying option theory to explain breach decisions and contract remedies include Alexander J. Triantis and George G. Triantis, Timing Problems in Contract Breach Decisions, 26 J. Legal Stud. (1997), and Paul G. Mahoney, Contract Remedies and Options Pricing, 24 J. Legal Stud. 139 (1995).

96. See 5 at 388,389 .

97. Ibid.; 4 n. 118 at $731 ; 6$ n. 86 at 205 .

98.13 at $566-7$.

99. See Alan Schwartz, The Default Rule Paradigm and the Limits of Contract Law, 3 So. Cal. Interdisc. L. J. 389 (1994).

100. See Bernstein, supra n. 4; Alan Schwartz, Cure and Revocation for Quality Defects: The Utility of Bargains, 16 B. Coll. Ind. \& Comm. L. Rev. 543 (1975) (rules of commodities exchanges regulate breach more explicitly than the UCC rules). Regarding the influence of the three Llewellyn proposals discussed here, the UCC does not require buyers who reject after delivery to resell, but the acceptance rules of $\S 2-606$ sometimes can be manipulated to reach this result; the Code adopts cover rules for buyers and sellers in $\S \S 2-706$ and $2-712$; and the UCC rejects a substantial performance rule - see $\S 2-$ 601 - but prevents a buyer who accepts from revoking acceptance unless the defects substantially impair the value of the contract. See $\S 2-608$. This rule raises some of the concerns discussed above, and parties routinely contract out by using repair and replacement clauses.

101. A comment to $\S$ II-A of the Revised Uniform Sales Act (1941) (a version that Llewellyn primarily wrote) advocated a merchant jury, explaining, "a court is rarely, and a jury almost never, equipped to pass with sound mercantile judgment on such a question as substantiality of a defect in performance in a particular trade."

102. Llewellyn's sensitivity to context also led him to recognize that relational contracts may require different legal treatment than other contracts. There are, he reported, a set of transactions that "lie half-way between mere reliance on the general spot market . . . and property-wise assurance of either outlet or supply by vertical integration." These deals include "output and requirements contracts, maximum and minimum contracts ... sliding scale price arrangements - these are symptomatic of an economy stabilizing itself along new lines." In these arrangements, "long-range buyer seller relations come to seem more important than exact definition of the risks to be shifted by the particular dicker. . .." 3 at 727. He later observed, "Our contract-law has as yet built no tools to really cope with this vexing and puzzling situation of fact," and that, in "standing relations," there is needed "a less-than-full contract damage type of sanction, for which 
no rules of damage have yet been evolved." 5 at 375 and 378. Llewellyn wisely did not attempt to solve relational contract problems; the economics requisite to understanding them are being created today.

103. As evidence for this claim, the American Economics Association once commissioned Kenneth Boulding and George Stigler to identify the canon. See Readings in Price Theory (K. E. Boulding and G. J. Stigler, eds., 1952). The editors focused on articles "of general theoretical interest. We have followed the policy of not confining ourselves to the most recent literature but have taken a comprehensive view of the economic literature of the past forty years." vi. Of the twenty-five reprinted articles, only one article, by Leonid Hurwicz, concerned game theory, and it was published in 1945. Of the fifteen articles published before 1940, only Ronald Coase's article on the firm was relevant to some of Llewellyn's concerns, but economists themselves did not appreciate this relevance until many years later. A vivid description of the informal way in which economics was done when Llewellyn worked is Robert M. Solow, How Did Economics Get That Way and What Way Did It Get?, 126 Daedalus 39 (1997). Oliver W. Williamson also has observed of realists generally that their program was hindered by an inability to do the relevant economics. See Oliver W. Williamson, "Revisiting Legal Realism: The Law, Economics and Organization Perspective," Working Paper No. 9512, Program in Law and Economics, School of Law, Berkeley (1996).

104. 12 at 704 . See also 5 at 403 .

105. 3 at 731 .

106. 5 at 371 .

107. 6, n. 25 at 175. Earlier Llewellyn observed "the most perplexing development of AngloAmerican sales practice: to wit, the spread of clauses of indecently broad limitation of buyer's remedies, and even of total exemption of seller from responsibility." 4 at 731 .

108. 5 at 386 . Llewellyn did not use the phrases "procedural unconscionability" and "substantive unconscionability." They are used here because they are a useful way to describe his thinking and because that thinking made possible the modern unconscionability vocabulary.

109. $6, \mathrm{n} .47$ at 185 . The insight that default rules cannot remedy unfaimess completely because the powerful party can avoid them apparently is reinvented in each generationsee Schwartz, supra n. 99, at 402-03 - and then ignored.

110. Llewellyn's 1939 book review (11) dealt almost exclusively with unconscionability issues and was cited sixty-seven times between 1972 and today. Llewellyn's two warranty articles ( 4 and 5) also had extensive discussions of unconscionability; these two articles were cited eighty times in the same period.

111. Unconscionability problems usually concern mass transactions (large firms and individual consumers). These transactions cannot be well understood without some competence in the economics of information, a field that George Stigler began in 1961. See George J. Stigler, The Economics of Information, 69 J. Pol. Econ. 213 (1961). For a modern review, see Alan Schwartz, Legal Implications of Imperfect Information in Consumer Markets, 151 J. of Inst. and Theor. Econ. 31 (1995). The discussion in Part V omits Llewellyn's products liability thought. Prior commentators observed that Llewellyn was among the earliest American scholars to advocate enterprise liability. See James R. Hackney, Jr., The Intellectual Origins of American Strict Products Liability: A Case Study in American Pragmatic Instrumentalism, 39 Am. J. Legal Hist. 
443, 482-7 (1995); Note, Karl Llewellyn and the Intellectual Foundations of Enterprise Liability Theory, 97 Yale L. J. 1131 (1988).

112. 1 at 673 . He thus identified with approval "the equivalency-idea," allegedly held by many courts, that bargains should be balanced. 3 at 745 .

113. 12 at 704. See also Ibid. at 700-3.

114. Ibid. at 704. In discussing courts, Llewellyn added that the goal is "the marking out of the limits of the permissible." Thus courts should strike "utterly unreasonable clauses." 12 at 704 .

115. For an interesting analysis of the difficulties involved in defining substantive unconscionability, see Richard Craswell, Property Rules and Liability Rules in Unconscionability and Related Doctrines, 60 U. Chi. L. Rev. 1, 20-9 (1993).

116. E.g., 4 at 712,$718 ; 5$.

117. 3 at 734 .

118. 3 at 732. Dennis Patterson, supra n. 4 at 175, argues, "The new conception engineered by Llewellyn [for interpreting contracts] presupposes that the meaning of the agreement of the parties does not depend exclusively or even primarily on the written terms of one or another document." Patterson does not refer to the contracts articles to demonstrate this view. Llewellyn agreed that custom and practice can illuminate the written word, but the Llewellyn of those articles would apply contract language unless it directed an unfair result.

119. Ibid. and 12 at 702 .

120. 1 at 673 . Llewellyn thus anticipated Fredrich Kessler, who many years later advocated this approach for courts exercising judicial oversight of insurance contracts. See Friedrich Kessler, Contracts of Adhesion-Some Thoughts About Freedom of Contract, 43 Colum. L. Rev. 629 (1943).

121. 12 at 704 .

122. See Draft Uniform Commercial Code (1996) $\S 2-206(\mathrm{~b})$ : “A term in a . . standard form . . . to which a consumer has manifested assent by a signature or other conduct is not part of the contract if the consumer could not reasonably have expected it unless the consumer expressly agrees to the term."

123. 12 at 704.

124. Ibid.

125. This criticism of a normative reasonable expectations test for identifying and responding to unconscionable terms has been made by numerous authors. See, e.g., Craswell, supra n. 116; Alan Schwartz, Proposals for Products Liability Reform: A Theoretical Synthesis, 97 Yale L. J. 353 (1988); Kenneth S. Abraham, Judge-Made Law and JudgeMade Insurance: Honoring the Reasonable Expectations of the Insured, 67 Va. L. Rev. 1151 (1981).

126. 3 n. 62 at 733. A court enforcing the "basic minimum," in this particular discussion, would override a disclaimer in order to permit the buyer to reject if the seller delivered goods different from those ordered. Llewellyn probably would permit the court to enforce the disclaimer in so far as it banned a suit for any consequential damages that the erroneous tender caused. Ibid. at 732-3. The same idea respecting disclaimers appears in 5 at 387.

127. 5 at $399-400$.

128. 12 at 705; and also ibid. at 703 (courts will insist upon the "minimum decencies" that are 
"essential to an enforceable bargain of a given type, or as being inherent in a bargain of that type") Traces of this position survive in comment 4 to UCC $\$ 2-313$, which recites that "a contract is normally a contract for a sale of something describable and described. A clause generally disclaiming 'all warranties, express or implied', cannot reduce the seller's obligation with respect to such description and therefore cannot be given literal effect. ..."

129. That a transaction type exists may be relevant to a finding of procedural unconscionability. For example, if sellers routinely accompany the sale of a particular product with a warranty, then a contract to sell that product with a disclaimer might surprise the buyer. This analysis would not make the warranty an "iron" term that sellers could not disclaim, but it would require a seller who uses a nonstandard disclaimer to bear a heightened disclosure burden.

130. See, e.g., 1 at $673 ; 3$ at 731 .

131. 1 at 678 .

132. 3, n. 47 at 725 and 734 .

133. A monopoly equilibrium exists when there are many firms but each charges the price that a single monopolist would have charged.

134. See Alan Schwartz and Louis Wilde, Imperfect Information in Markets for Contract Terms: The Examples of Warranties and Security Interests, 69 Va. L. Rev. 1387 (1983).

135. Modern views respecting procedural unconscionability and related doctrines are summarized in Richard Craswell and Alan Schwartz, Foundations of Contract Law 287341 (1994).

136. 5 at 358 .

137. Ibid., n. 58, 364-5.

138. 6 at 207. Llewellyn later justified the need for sales law reform in part because some courts failed to read the Uniform Sales Act to obtain just results. "An instance is found in the whole series of difficulties over implied warranty, and over the degree to which or manner in which various warranty-responsibilities can be avoided in transactions in which they should be present." 13 at 560 . See also the earlier statement in 5 at 384-5: "the one thing which should never be allowed to be negated - at least as a condition, ... is a description when taken seriously. . . . Surely a case is to be made for [Uniform Sales Act] Section $14 \ldots$ being an iron section whose effect no agreement can upset. . ." Llewellyn meant here that if the seller described the goods as grade A but the contract recited that the buyer bears the risk that the goods might turn out to be another grade, the buyer "at least" should be permitted to reject grade B goods, and perhaps should be permitted to assert the other buyer remedies.

139. 3 at 744 .

140. 5 at 402 .

141. 10 at 743 ; also at 726 and 741 . In eighteenth century England, a warranty of quality may have been implied on the basis of a sound price only when the seller was aware of the defect at the time of sale. See Oldham, supra n. 18, at 1977-8.

142. 5 at $400-1$.

143. 12 at 702. This idea also appears in comment 4 to UCC $\$ 2-313$, where courts are advised to give "consideration . . . to the fact that the probability is small that a real price is intended to be exchanged for a pseudo-obligation."

144. See Alan Schwartz and Robert E. Scott, Commercial Law: Principles and Policies 
204-7 (2d ed., 1991). Llewellyn thus mistakenly said of what is now the standard warranty for manufactured goods, under which the seller agrees to repair or replace defective parts for a limited period but precludes rejection for minor defects and excludes recovery for consequential damages, "that precious commodity Justice must be viewed as being as scarce as the scarce economic goods." 5 at $400-1$.

145. The driving force in this example apparently is the low failure probability. If the failure probability were $3 \%$, however, the disclaimer price would be $97.3 \%$ of the warranty price. Failure probabilities above $3 \%$ for standard manufactured products seem uncommon. Also, if the ratio of fixed to variable costs were higher, the price difference would be smaller. In the example above, if the seller's fixed cost were $\$ 300$ per unit and her variable cost $\$ 800$, a disclaimer would reduce the price by $\$ 8$ on an $\$ 1,100$ item. The UCC permits sellers to disclaim implied warranties - see $\S 2-316(2)$-but also permits courts to strike these disclaimers under $\S 2-302$ if they are unconscionable.

146. Winand Emons, The Theory of Warranty Contracts, 3 J. Econ. Surveys 43, 54 (1989).

147. Neil Duxbury observed that Llewellyn, "far from being a typecast rule-sceptic, was adamant that rules 'guide' judicial decision-making." See The Reinvention of American Legal Realism, 12 Legal Stud. 137, 143 (1992) (footnote omitted). Fisher also noted Llewellyn's belief that rules could confine decisionmakers. On the other hand, Bechtler, supra n. 57 at 25, Leiter, supra n. 4, Fisher, and others associate Llewellyn with rule scepticism. Twining frequently suggests that Llewellyn was an ethical relativist. Llewellyn has been associated with the position that legal realists were not interested in policy on the basis of his view, expressed in Some Realism about Realism-Responding to Dean Pound, 44 Harv. L. Rev. 1222 (1931), that scholars should put the normative aside for a time in order to study how the legal system actually works. Fisher associates Llewellyn, among others, with having undermined democratic theory, a part of view (6), by allegedly showing that "judges deciding individual controversies often derive little guidance if any from statutes (enacted by elected representatives of the people) or from common law rules (implicitly democratically ratified through the legislature's inaction). ..."Fisher, supra n. 34, at 284. The preceding notes show that Llewellyn has been identified with the other positions. One could add to the list that realists believed scholars should do empirical research about how law affects society. Llewellyn was sympathetic to this project, but was not an empiricist when wearing his contract scholar (as contrasted with his sociologist) hat. 